\title{
Multiple aberrant hormone receptors in Cushing's syndrome
}

\section{Nada El Ghorayeb, Isabelle Bourdeau and André Lacroix}

Division of Endocrinology, Department of Medicine, Centre de recherche du CHUM (CRCHUM), Université de Montréal, 900, Rue Saint-Denis, Room R08-474, Montréal, Québec H2X 0A9, Canada
Correspondence should be addressed to A Lacroix Email andre.lacroix@umontreal.ca

\begin{abstract}
The mechanisms regulating cortisol production when ACTH of pituitary origin is suppressed in primary adrenal causes of Cushing's syndrome (CS) include diverse genetic and molecular mechanisms. These can lead either to constitutive activation of the CAMP system and steroidogenesis or to its regulation exerted by the aberrant adrenal expression of several hormone receptors, particularly G-protein coupled hormone receptors (GPCR) and their ligands. Screening for aberrant expression of GPCR in bilateral macronodular adrenal hyperplasia (BMAH) and unilateral adrenal tumors of patients with overt or subclinical CS demonstrates the frequent co-expression of several receptors. Aberrant hormone receptors can also exert their activity by regulating the paracrine secretion of ACTH or other ligands for those receptors in BMAH or unilateral tumors. The aberrant expression of hormone receptors is not limited to adrenal CS but can be implicated in other endocrine tumors including primary aldosteronism and Cushing's disease. Targeted therapies to block the aberrant receptors or their ligands could become useful in the future.
\end{abstract}

\section{Introduction}

Cushing's syndrome (CS) results from chronic exposure to increased concentrations of circulating free cortisol activating glucocorticoid and mineralocorticoid receptors expressed in most tissues $(1,2)$. Corticotropin-independent causes account for $\sim 15-25 \%$ of cases of endogenous overt hypercortisolism, which are mainly due to adrenal adenomas and carcinomas $(1,2)$. Rare causes of CS $(<2 \%)$ include primary bilateral macronodular adrenal hyperplasia (BMAH) and primary pigmented nodular adrenal disease (PPNAD) either as isolated disease or as part of Carney complex (CNC) $(1,2)$. Unilateral or bilateral adrenal incidentalomas found in $\sim 4 \%$ of adults frequently secrete dysregulated amounts of cortisol producing sub-clinical CS (3). Regulation of cortisol secretion is

Invited Authors' profile

André Lacroix is professor at the Department of Medicine, Université de Montréal. His research focuses on molecular mechanisms of adrenal tumors, aberrant hormone receptors in adrenal tumors and hyperplasia, and new therapies for pituitary and adrenal tumors.

Nada El Ghorayeb obtained her MD and certification in Internal Medicine from St Georges Faculty of postgraduate medical education, Balamand University, Lebanon. She is currently doing a two-year clinical and research fellowship in adrenal disorders at the Centre hospitalier de l'Université de Montréal (CHUM) with Professors André Lacroix and Isabelle Bourdeau.

(C) 2015 European Society of Endocrinology Printed in Great Britain Published by Bioscientifica Ltd.
This article is adapted from work presented at IMPROCUSH-1, 12-14 October 2014. The meeting was supported by the European Science Foundation, Deutsche

Forschungsgemeinschaft, Carl Friedrich von Siemens Stiftung, European Neuroendo-

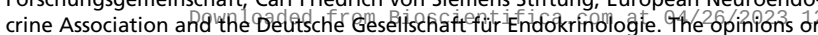
views expressed in this article are those of the authors, and do not necessarikjiefferfe access

the opinions or recommendations of the supporters of the symposium. 
exerted mainly by the binding of adrenocorticotropin (ACTH) to its specific melanocortin type 2 receptor (MC2R), a G-protein coupled hormone receptor (GPCR) expressed on zona fasciculata cells that interacts with MC2R-associated proteins (4); the ensuing dissociation of Gs- $\alpha$ subunit and activation of adenylate cyclase (AC) generates cAMP from ATP (5). The binding of cAMP to specific domains of the regulatory subunits of PKA dissociates the tetramer, releases the catalytic subunit (PRKACA) that phosphorylates different intracellular targets, including the transcription factor CREB; the latter activates the transcription of cAMP-responsive elementcontaining genes in the nucleus including cholesterol transporters and steroidogenic enzymes (6) (Fig. 1). In primary adrenal causes of CS, the excess secretion of cortisol suppresses the production of corticotropin-releasing hormone $(\mathrm{CRH})$ in hypothalamus and of ACTH by the corticotroph cells (2) (Fig. 1). The mechanisms regulating cortisol production, despite suppression of ACTH, were partially identified two decades ago when it was demonstrated that cortisol could be regulated by the aberrant expression and function of diverse GPCR, particularly in $\mathrm{BMAH}$, or in some unilateral cortisol-secreting adenomas (7). More recently, diverse genetic and molecular mechanisms that lead to increased production of cAMP and activation of steroidogenesis were elucidated (2). In $35-65 \%$ of unilateral adrenal adenomas with overt CS, constitutive secretion results from mutations in the catalytic subunit of protein kinase A (PRKACA). Those mutations are rare in adenomas secreting less cortisol $(8,9$, $10,11,12)$. Somatic mutations of GNAS (encoding Gas) and $\beta$-catenin (CTNNB1) were found in 5-17 and 16\% respectively of cortisol secreting adenomas $(10,11,12)$. The mechanisms regulating steroidogenesis in adrenocortical carcinoma remain largely unknown. Isolated or familial PPNAD and CNC result most frequently from inactivating mutations of the gene coding for protein kinase A regulatory-subunit typeI-A (PRKAR1A) leading to increased PKA signalling $(13,14,15,16)$. Inactivating mutations in phosphodiesterase $11 \mathrm{~A}$ isoform 4 gene (PDE11A) or $8 \mathrm{~B}$ (PDE8B) have been identified in rare kindreds with non-pigmented micronodular hyperplasia without PRKAR1A mutations $(17,18)$. In McCune-Albright syndrome, or in rare cases of $\mathrm{BMAH}$, activating mutations of the Gs $\alpha$ subunit of heterotrimeric G protein also termed $g s p$ mutations (GNAS) occur in a mosaic pattern in the adrenal during early embryogenesis resulting in constitutive activation of the cAMP pathway $(19,20,21,22)$. In BMAH, activating mutations in MC2R gene have been described in only two cases $(23,24,25,26)$.
The most important recent finding in this field is the identification of germline mutations of Armadillo RepeatContaining Protein 5 (ARMC5) in up to $55 \%$ of cases $(25 \%$ in larger recent series) of apparently sporadic and familial BMAH; additional biallelic ARMC5 somatic mutations are found in the adrenal macronodules $(27,28,29,30,31)$. ARMC5 inactivation decreases the expression of both MC2R and various steroidogenic enzymes although it has no apparent link to the cAMP pathway (30). The possible association between meningioma and BMAH was confirmed by the finding of a somatic frameshift mutation in ARMC5 in the intracranial meningothelial tissues of a patient with familial BMAH and germline ARMC5 mutation $(27,32,33)$.

In contrast to mechanisms that would mainly lead to constitutive activation of the cAMP system, abnormal regulation of steroidogenesis can result from the aberrant adrenal expression of several hormone receptors, particularly GPCR and their ligands, which will be reviewed here. Aberrant hormone receptors can also exert their activity by regulating the paracrine secretion of ACTH or other ligands for those receptors in BMAH or unilateral tumors $(34,35)$.

\section{Methods}

For this review, we performed a search in the PubMed database since 1970 using several terms including adrenal gland, CS, AIMAH, BMAH, PMAH, hypercortisolism, Cushing's disease (CD), aberrant expression of GPCR, primary aldosteronism (PA), paracrine, autocrine and the usual denominations of the various regulatory factors identified in the adrenal tissue, such as ACTH, glucosedependent insulinotropic peptide (GIPR), vasopressin, serotonin or 5-hydroxytryptamine, catecholamine, angiotensin II, luteinizing hormone (LH) and glucagon. We will focus on the studies that examined the diversity, prevalence, potential molecular mechanisms and new pharmacotherapy of aberrant GPCR and their ligands in adrenocortical hyperfunction. Finally, we will briefly discuss the role of aberrant GPCR in other endocrine tumors including in PA and CD.

\section{Historical background and evolution of aberrant expression of GPCR in CS}

The concept of aberrant expression of hormone receptors in adrenal tumors was proposed initially by Schorr \& Ney in 1971 (36); Hamet et al. (37) described the first case of food-dependent CS in 1987 in a patient with unilateral 


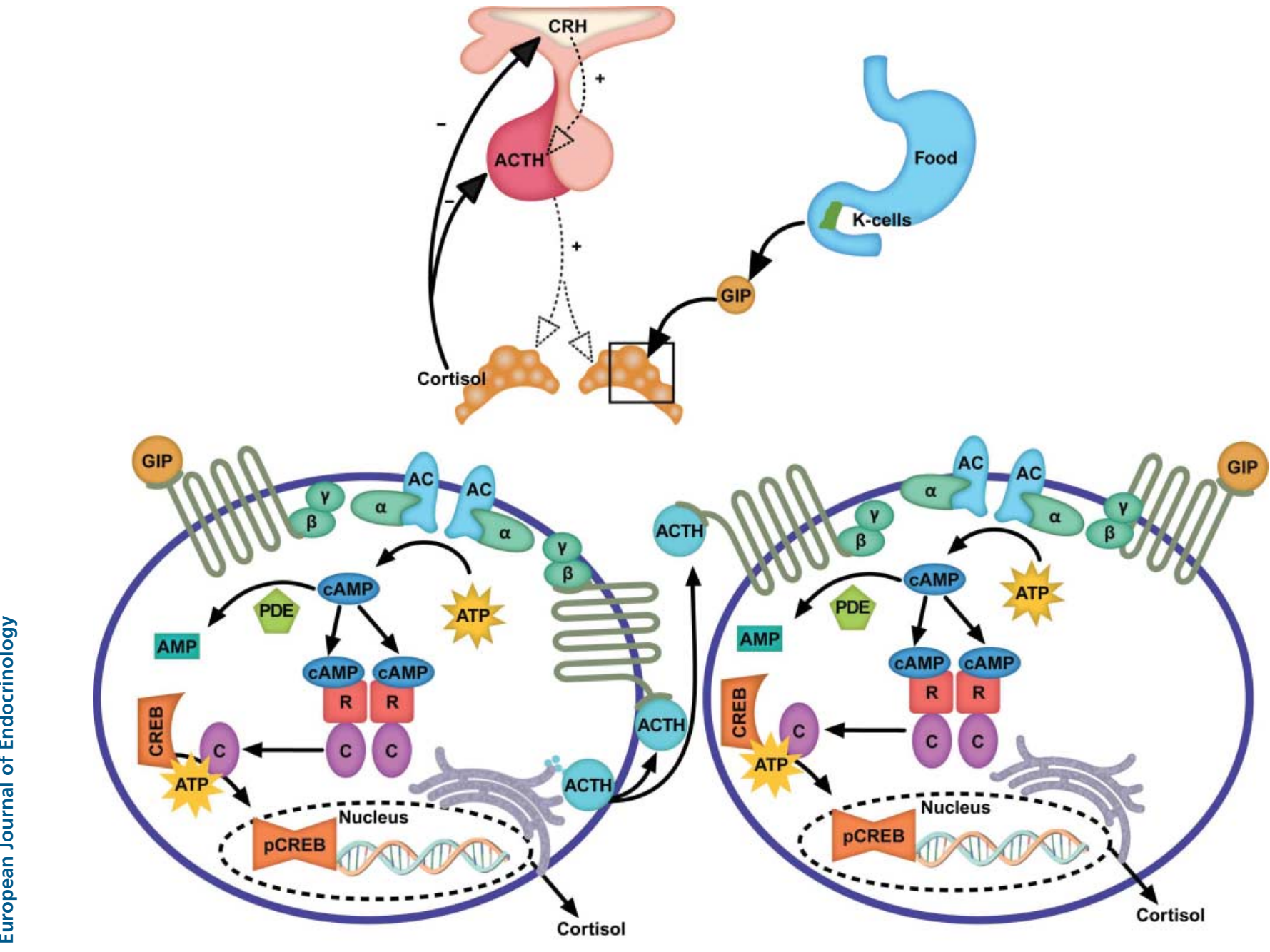

\section{Figure 1}

In primary adrenal causes of CS, the abnormal regulation of steroidogenesis can result from the aberrant adrenal expression of several hormone receptors, particularly GPCR and their ligands illustrated here by the ectopic expression of GIP receptor. GIP levels increase after meals. GIP binds to its receptor expressed on zona fasciculata cells and induces the activation of intracellular cascade similar to the one activated normally by the binding of ACTH to MC2R. The ensuing dissociation of Gs- $\alpha$ subunit and activation of adenylate cyclase (AC) generates camp from ATP. The binding of CAMP to specific domains of the regulatory subunits of PKA, dissociates the tetramer, releases

adenoma in whom the cortisol secretion presented an inverse rhythm with low fasting morning plasma levels that increased postprandially. In 1992 Lacroix et al. (38) and Reznik et al. (39) identified that food-dependent adrenal CS in two patients with BMAH resulted from the catalytic subunit (PRKACA) which phosphorylates different intracellular targets, including the transcription factor CREB; the latter activates the transcription of CAMP-responsive element-containing genes in the nucleus including cholesterol transporters and steroidogenic enzymes. The excess secretion of cortisol suppresses the production of $\mathrm{CRH}$ in hypothalamus and of ACTH by the pituitary corticotroph cells. In BMAH tissues, cortisol production is controlled both by aberrant GPCR and autocrine/paracrine ACTH regulatory mechanisms. ACTH released from zona fasciculata cells binds to $M C 2 R$ and amplifies the aberrant receptor response.

aberrant responsiveness of adrenal cells to physiological secretion of GIP presumably resulting from expression of ectopic GIP receptors on adrenal cells. This was followed by an extensive number of publications of case reports and small series of patients during the next three decades as 
summarized in previous reviews $(7,40,41)$. In most patients with BMAH and a lesser proportion of those with unilateral adrenal adenomas with clinical or subclinical CS, aberrant GPCRs regulate steroidogenesis by mimicking the cellular events that are triggered normally by ACTH receptor (MC2R). Steroidogenesis can be driven by the expression of ectopic receptors that are not expressed at significant levels in normal zona fasciculata cells, such as those for GIPR, beta-adrenergic receptors ( $\beta$-AR), vasopressin $\left(\mathrm{V}_{2}-\mathrm{V}_{3}\right.$-vasopressin receptor), serotonin $\left(5-\mathrm{HT}_{7}\right.$ receptor), glucagon (GCGR) and probably angiotensin II (AT1R). It can also result from increased expression or increased coupling to steroidogenesis of eutopic receptors such as those for vasopressin ( $\mathrm{V}_{1}$-vasopressin receptor), LH/human chorionic gonadotropin (LHCGR), or serotonin $\left(5-\mathrm{HT}_{4}\right.$ receptor $)(7,40,42,43)$. The clinical manifestation of aberrant GPCR expression occasionally results in specific patterns of CS, for example in fooddependent CS with fasting hypocortisolism (ectopic GIPR) or pregnancy/menopause induced CS (aberrant LHCGR) (40); in most cases, the presence of aberrant receptor does not modify significantly the clinical presentation of CS. However, the identification of aberrant regulation offers the perspective of potential pharmacological therapeutic options that target GPCR or their ligands in an attempt to avoid bilateral adrenalectomy that is the current standard therapy of BMAH $(43,44)$.

\section{Systematic screening for aberrant expression of GPCR in overt and subclinical CS demonstrates the frequent co-expression of several receptors}

In vivo investigation protocols were designed to systematically evaluate the potential presence of aberrant receptors. An ACTH-independent change of cortisol or other steroids $(>50 \%)$ in response to physiological (upright posture, mixed meals) and pharmacologic (gonadotropin-releasing hormone (GnRH), thyrotropinreleasing hormone (TRH), vasopressin, glucagon, metoclopramide) tests that modulate the levels of ligands for the potential aberrant receptors was examined $(41,45,46$, $47,48)$. Following the initial finding of a positive response, further stimulatory tests can be conducted to precisely define the hormone and the specific receptor type implicated (41); for instance, if a positive response was detected following a mixed meal, the following tests would be conducted to document the presence of a GIP receptor: stimulation by oral glucose, lipids and proteins, non-stimulation by IV glucose, inhibition by octreotide and finally stimulation with GIP perfusion (38).

Abnormal expression of more than one type of GPCR was demonstrated in many systematic studies of patients with subclinical or overt CS $(41,45,46,47,48,49,50,51$, 52). Table 1 summarizes the results of five systematic studies that have screened for aberrant expression of GPCR in overt and subclinical CS. Among patients with BMAH, including 52 with CS and 35 with subclinical Cushing's syndrome (SCS), 80\% showed aberrant cortisol responses to at least one stimulus with multiple responses within individual patients occurring for up to four stimuli in 50\% of the patients $(45,46,47,48,49)$. The percentage of patients with aberrant responses was less frequent in patients with unilateral adenomas and overt CS (45), possibly reflecting the higher prevalence of PRKACA mutations in this category of patients (8); however in patients with unilateral adenoma and mild CS or SCS the percentage of patients with aberrant responses were similar to those in BMAH patients (46). Vasopressin (AVP) and serotonin HTR4 agonists were the most prevalent hormonal stimulus triggering aberrant responses in vivo $(45,46$, $47,48,49)$. In vitro studies did not always correlate with in vivo responses; hyper-responsiveness to AVP was not consistently related to vasopressin receptor overexpression, but may be explained by more efficient coupling pathways or by the indirect action of AVP through an autocrine/paracrine mechanism (53). Hofland et al. (48) compared in-vitro data to in-vivo testing and found some discrepancies, suggesting that the criterion of $25-50 \%$ serum cortisol elevation to establish the partial/complete responsiveness should be re-evaluated, at least when AVPRIA and $5-\mathrm{HT}_{4}$ receptors are tested . Moreover, the pathogenesis of AVP-mediated cortisol overproduction was linked to an aberrant coupling of normal levels of AVPR1A to the induction of CYP11B1 (48).

Table 2 presents the characteristics of the different aberrant GPCR; ectopic GIP receptor expression was the most studied GPCR in BMAH and unilateral adenomas, reported in more than 30 cases (41). Food ingestion and particularly its lipid and glucose content stimulate the release of GIP, a 42 amino acid peptide hormone from intestinal K cell (Fig. 1). Normal individuals often present a modest elevation in cortisol after mid-day meal following ACTH stimulation by the protein content of the diet (7). In patients with GIP-dependent CS, as their pituitary ACTH levels become suppressed, they can present low fasting plasma cortisol levels in morning, which increase following physiological elevation of GIP after meals. Fasting cortisol levels may not always be suppressed 
Table 1 Systematic studies for aberrant expression of GPCR in patients with primary adrenal lesions with overt or subclinical Cushing's syndrome.

\begin{tabular}{|c|c|c|c|c|c|c|c|c|}
\hline \multirow[b]{2}{*}{ References } & \multicolumn{4}{|c|}{ ВМАН } & \multicolumn{4}{|c|}{ Unilateral adrenocortical tumors } \\
\hline & $n$ & $\begin{array}{c}\text { Aberrant } \\
\text { responses (\%) }\end{array}$ & $\begin{array}{c}\text { Several aberrant } \\
\text { responses (\%) }\end{array}$ & Stimuli (\%) & $n$ & $\begin{array}{c}\text { Aberrant } \\
\text { responses (\%) }\end{array}$ & $\begin{array}{c}\text { Several aberrant } \\
\text { responses }(\%)\end{array}$ & Stimuli (\%) \\
\hline$(45)$ & $6 \mathrm{CS}$ & $6 / 6(100 \%)$ & $2 / 6(33 \%)$ & $\begin{array}{l}\text { Posture }(33 \%) \\
\text { AVP } 33 \% \\
\text { Mixed meal } \\
\quad(\text { GIP) } 33 \%\end{array}$ & $14 \mathrm{CS}$ & $3 / 14(21 \%)$ & $0 / 14(0 \%)$ & $\begin{array}{l}\text { Posture } 7 \% \\
\text { AVP }(7 \%) \\
\text { Mixed meal (GIP) } \\
\quad 7 \%\end{array}$ \\
\hline (46) & - & - & - & - & 21 SCS & $21 / 21(100 \%)$ & $18 / 21(86 \%)$ & $\begin{array}{r}\text { Terlipressin } 90 \% \\
\text { cisapride } 81 \%\end{array}$ \\
\hline (49) & $14 \mathrm{CS}$ & $9 / 14(64 \%)$ & $N A^{a}$ & $\begin{array}{l}\text { AVP } 45.5 \% \\
\text { Posture } 36 \% \\
\text { TRH } 33 \%{ }^{\mathrm{b}}\end{array}$ & $12 \mathrm{CS}$ & NA & NA & $\begin{array}{l}\text { AVP } 40 \% \\
\text { Posture } 25 \% \\
\text { Glucagon } 18 \%\end{array}$ \\
\hline (47) & $\begin{array}{l}10 \mathrm{CS} \\
22 \mathrm{SCS}\end{array}$ & $28 / 32(87 \%)$ & $21 / 32(66 \%)$ & $\begin{array}{l}\text { Posture } 67 \% \\
\text { Metoclopra- } \\
\text { mide } 56 \% \\
\text { Glucagon in } \\
\text { SCS } 58 \%{ }^{c}\end{array}$ & - & - & - & - \\
\hline (48) & $\begin{array}{l}22 \mathrm{CS} \\
13 \mathrm{SCS}\end{array}$ & $27 / 35(77 \%)$ & $17 / 35(49 \%)$ & $\begin{array}{l}\text { Posture } 50 \% \\
\text { AVP } 52 \%\end{array}$ & - & - & - & - \\
\hline Total & $\begin{array}{l}52 \mathrm{CS} \\
35 \mathrm{SCS}\end{array}$ & $70 / 87(80 \%)$ & $40 / 73(55 \%)$ & & $\begin{array}{l}26 \mathrm{CS} \\
21 \mathrm{SCS}\end{array}$ & $17 / 35(49 \%)$ & $18 / 35(51 \%)$ & \\
\hline
\end{tabular}

$n$, number of patients; aberrant responses, frequency of patients who responded to at least one stimulus; several aberrant responses, frequency of patients who responded to several stimuli; stimuli, type of stimuli inducing the highest percentage of aberrant responses; SCS, subclinical Cushing's syndrome; CS, clinical Cushing's syndrome; NA: data not available.

${ }^{a}$ Details on the exact number of patients who responded were unavailable.

$\mathrm{b}_{5} \mathrm{HT}_{4}$ agonists stimulatory test was not conducted in this study.

${ }^{c}$ Cortisol inhibition by octreotide in three CS patients who responded to mixed meal, and in 12 of 13 (92\%) patients with SCS.

because other aberrant GPCR can be expressed with GIPR in the same tissue such as LHCGR $(52,54,55)$ and HTR4 (52). The expression of the GIP receptor can be detected in the early phases of adrenal hyperplasia $(56,57)$. Rarely, the adrenal nodules in patients with GIP-dependent BMAH can progress asynchronously, first in one adrenal, later in the other (57); the larger nodules were the result of secondary clonal proliferation events in addition to GIPR overexpression (56). GIP increases cAMP production and DNA synthesis in GIP-dependent cortisolsecreting tissue (Fig. 1) suggesting that GIP can be implicated both in steroidogenesis and cellular proliferation (58). It was suggested that chronic stimulation by ACTH could result in increased GIPR expression (59), but other studies did not confirm GIPR overexpression in the adrenal glands of patients with $\mathrm{CD}$ or ectopic ACTH syndrome $(58,60,61,62)$. The demonstration that bovine adrenal cells transfected with the GIP receptor and injected under the renal capsule in mice leads to the development of hyperplastic adrenals and hypercortisolism further supported a role of the ectopic receptor in steroidogenesis and cell proliferation (63).

Transient CS appearing during sequential pregnancies with spontaneous resolution after delivery led to the identification of aberrant LH/human chorionic gonadotrophin (hCG) receptors; sustained increase of LH secretion that is the hallmark of the postmenopausal period resulted in persistent CS $(64,65)$. Other cases of CS from BMAH or adrenal adenoma outside of pregnancy were also found with aberrant cortisol response to injection of GnRH and hCG $(55,66)$. In one adrenal adenoma, a heterozygous mutation of Gsa at codon 201 was found in addition to the aberrant LH/CG receptors (67). Kero et al. (68) used transgenic female mice as a model to demonstrate that chronically elevated serum LH following gonadectomy induced functional $\mathrm{LH}$ receptor expression in mouse adrenal cortex, leading to adrenal hyperplasia and LH-dependent hypercortisolism. Other GPCR overexpressed in BMAH tissues were identified by using transcriptome approach, including those for motilin (MLNR), gamma-aminobutyric acid (GABBR1) and a2 adrenergic receptor (ADRA2A) (69). ADRA2A receptors previously found in adrenocortical carcinoma cells of rats (70) were overexpressed in the human NCI H295R adrenocortical carcinoma cells as well as in 13 of 18 patients with BMAH. Furthermore, clonidine led to an increase in basal cortisol levels, which was counteracted by the ADRA2A antagonist yohimbine (69). 
Table 2 Types of GPCR in BMAH or unilateral adrenocortical tumors of patients with overt or subclinical Cushing's syndrome. Some pertinent references for each receptor are cited in order to respect maximal number of references allocated.

\begin{tabular}{l} 
Aberrant receptor \\
\hline GIP receptor (ectopic) (37, 38, 39, \\
$\quad 45,52,54,55,57)$ \\
Vasopressin receptor \\
$V_{1}$ (eutopic) $(32,45,49,50,53,78$, \\
$79,84,105,144)$ \\
$V_{2}, V_{3}$ (ectopic) (32, 79) \\
$\beta$-adrenergic receptor (ectopic)
\end{tabular}

$(45,78,117)$

AT-1 receptor (ectopic) $(55,145)$

LH/hCG receptor (eutopic)

$(50,52,54,55,64,121)$

$5-\mathrm{HT}_{4}$ receptor (eutopic) $(64,79,85)$

$5-\mathrm{HT}_{7}$ receptor (ectopic) $(71,87)$

Glucagon receptor (ectopic) $(47,72,73,74,75)$

\begin{tabular}{l}
\hline Phenotype \\
\hline $\begin{array}{l}\text { Food-induced } \\
\text { hypercortisolism } \\
\text { Upright posture-related } \\
\text { hypercortisolism }\end{array}$
\end{tabular}

Upright posture Insulin-induced hypoglycemia exercise/ stress test hypercortisolism

Posture-dependent hypercortisolism

Pregnancy (transient)

Postmenopausal (persistent)-dependent hypercortisolism

Serotonin-dependent hypercortisolism

Hypoglycemia ?

\begin{tabular}{l} 
In vivo screening protocol \\
\hline Mixed meal \\
Oral glucose \\
Upright posture \\
AVP/desmopressin
\end{tabular}

Upright posture Isoproterenol

( $\beta 1$-agonist)

Salbutamol ( $\beta 2$-agonist)

Upright posture

Angiotensin II

$\mathrm{GnRH}$

hCG, Recombinant LH

5-HT4 receptor agonists (metoclopramide, cisapride)

Intravenous glucagon

\begin{tabular}{l} 
Co-expression \\
\hline $\mathrm{LH} / \mathrm{hCG} \mathrm{R}$ \\
$5-\mathrm{HT}_{4} \mathrm{R}$ \\
$\mathrm{B}_{\mathrm{AR}}$ \\
$5-\mathrm{HT}_{4} \mathrm{R}$
\end{tabular}

$5-\mathrm{HT}_{4} \mathrm{R}$

GIPR

LH/hCG R

GIPR

$\beta-A R$

$\mathrm{V}_{1}$

$5-\mathrm{HT}_{4} \mathrm{R}$

$\beta$-blockers

Targeted medical therapy

Octreotide, pasireotide

GIPR antagonist

Specific AVP receptors antagonist

AT-1 receptor antagonist

Long-acting GnRH agonist (leuprolide acetate)

$5-\mathrm{HT}_{4}$ receptor antagonist (GR113808)

$5-\mathrm{HT}_{7}$ receptor anta-

gonist

Octreotide LH/hCG R

Several in vitro studies have further supported the expression of GPCRs in human adrenocortical benign and malignant tumors; these include thyrotropin, follicle stimulating hormone and interleukin 1, in addition to those clearly confirmed in vivo $(7,40)$. Furthermore, $5-\mathrm{HT}_{7}$ receptor agonists were also found to stimulate cortisol production from an adrenal carcinoma that also produced rennin (71). The presence of ectopic glucagon receptors was demonstrated in patients with subclinical or overt CS $(47,72,73,74,75)$. Injection of glucagon increased cortisol in two out of 13 patients with BMAH or unilateral adenoma. In vitro studies revealed the presence of glucagon receptor-like immunoreactivity in clusters of spongiocytic cells in adrenal tissues from patients who were sensitive in vivo to glucagons (75). Expression of somatostatin receptors SSTRs (particularly of SSTR1-3) was increased in PPNAD tissues carrying a PRKAR1A mutation compared to normal adrenal and to tissues from other adrenal diseases. In vivo cortisol reduction seen in some patients following octreotide administration (although not significant) indicates that somatostatin analogues may be considered as treatment for PPNAD (76). Despite the initial report of ectopic response of adrenal tumors in vitro to thyrotropin (36), no further reports of such a response were identified in the following systematic studies, which therefore do not appear to justify systematic testing with TRH $(45,46,47,48,49)$.

\section{Aberrant GPCR in familial cases of BMAH}

BMAH was initially believed to be a sporadic disease, suggesting somatic mutations occurring in adrenal progenitor cells during embryogenesis. However, several reports of familial cases with autosomal dominant transmission patterns have been published suggesting germline genetic etiology $(32,77,78,79,80,81,82,83)$. In familial BMAH without other genetic syndrome (such as MEN-1, polyposis coli), specific aberrant GPCR including vasopressin, $\beta$-adrenergic and $\mathrm{HT} 4$ receptors were found in all members from the same family; in contrast, in one large Brazilian family, the pattern of aberrant receptors varied between the different affected members $(27,32,77,78,79$, $80,81,82,83)$. The relation between ARMC5 mutation and aberrant GPCR has not been examined in detail yet. Preliminary studies have found that ARMC5 mutation carriers can present aberrant response to upright posture, vasopressin and metoclopramide tests $(30,31,32,36)$. In contrast, none of the six patients with food-dependent CS carried ARMC5 mutations (30, 31). Further studies will be necessary to clarify the relation between ARMC5 
mutations and aberrant GPCR or autocrine production of $\mathrm{ACTH}$ in BMAH tissues.

\section{Cortisol is also regulated by the paracrine/autocrine production of ligands for the aberrant receptors in adrenocortical tumors and hyperplasias}

Paracrine regulatory mechanisms of cortisol secretion were proposed following the demonstration of increased adrenocortical expression of pro-opiomelanocortin (POMC)/ACTH, serotonin, vasopressin or glucagon in some affected adrenal tissues (53, 72, 84, 85, 86, 87). A complex paracrine regulation was confirmed by the recent demonstration of expression of POMC in clusters of steroidogenic cells in the majority of 30 tissues studied from patients with BMAH and CS (34). Prohormone convertase 1 was co-expressed in POMC-producing cells allowing maturation to active corticotropin. BMAH tissues released ACTH and cortisol episodically during perifusion studies, but this secretion was not regulated by $\mathrm{CRH}$, dexamethasone or the GR antagonist mifepristone. In contrast, in BMAH tissues expressing aberrant GPCR, GIP, serotonin or hCG led to release of ACTH, and cortisol increase was inhibited $40 \%$ by the MC2R antagonist ACTH (7-38) in these tissues (34). Cortisol production in BMAH is thus controlled both by aberrant GPCR and autocrine ACTH, which amplifies the aberrant receptor effects. GIP also promoted the production of ACTH in human adrenocortical carcinoma H295R cells transfected with GIPR (88). BMAH tissues may also produce serotonin, vasopressin, glucagon and other factors that suggest further paracrine regulatory loops of cortisol secretion and cell proliferation. A subpopulation of adrenocortical cells of BMAH tissues was found to produce serotonin; cortisol secretion appeared to be stimulated by two mechanisms including a direct action on steroidogenic cells involving overexpressed $5-\mathrm{HT}_{4}$ and/or $5-\mathrm{HT}_{7}$ receptors and an indirect effect through activation of ACTH release by adrenocortical gonadal-like cells (35). The confirmation of a role of autocrine ACTH will await demonstration that blockade of adrenal ACTH receptors in vivo will reverse hypercortisolism in affected patients (89).

\section{Aberrant regulation by nuclear hormone receptors}

An in vivo paradoxical increase in urinary free cortisol during the 6-day dexamethasone suppression test was found in $69-75 \%$ of two small series of patients with
PPNAD $(90,91)$. In another study, no paradoxical increase in cortisol was seen in nine patients with BMAH, but it was observed in three of 15 patients with a unilateral adenoma (90). Dexamethasone also increased cortisol production in the adrenal tissue dispersed from the PPNAD patients; this response was correlated with a striking glucocorticoid receptor over-expression in the nodules (92). The paradoxical stimulation of cortisol production by dexamethasone was mediated by the glucocorticoid receptor and inhibited by specific inhibitors of PKA (91). In a patient with PPNAD, who increased cortisol secretion during pregnancy and oral contraceptive use (and dexamethasone), $\beta$-estradiol $\left(E_{2}\right)$ stimulated cortisol secretion in a dose-response manner in the absence of ACTH (93). In PPNAD tissues associated with CS, $\mathrm{E}_{2}$ abnormally stimulated cortisol secretion through activation of overexpressed estrogen receptors ER $\alpha$ and $G$ protein-coupled receptor 30 (GRP30) (94). This finding may explain why the CS of PPNAD is more frequent after puberty in female patients with CNC (94).

\section{Aberant GPCR is not a unique feature of zona fasciculata cells}

The two major causes of PA are aldosterone-producing adenomas (APA) observed in $30-40 \%$ of patients and bilateral idiopathic adrenal hyperplasia detected in 60$70 \%$ of cases. The mechanisms regulating aldosterone production, while renin and angiotensin II are suppressed, are not fully elucidated. Somatic mutations of genes encoding the potassium channel KCNJ5 (95), L-type calcium channel (96) and sodium/potassium and calcium ATPases (97) were found to stimulate aldosterone synthase expression and aldosterone hypersecretion through calcium influx in $\sim 50 \%$ of aldosteronomas; their role in cell proliferation are less well defined, but these mutations may also play a role in the clonal expansion of the larger aldosterone secreting adrenal nodules. Such mutations are not found in PA secondary to idiopathic bilateral hyperplasia except in rare kindreds with familial hyperaldosteronism type III (98). In vitro studies have suggested that some GPCRs are abnormally expressed in APA, including ectopic expression of $\mathrm{GnRH}$ receptor and TRH receptor $(99,100)$ and eutopic overexpression of MC2R (100, 101, 102), 5- $\mathrm{HT}_{4} \mathrm{R}$ (103), AT-1R (100), LH/hCG receptor (104), $\mathrm{V}_{1}$-vasopressin receptor $(105,106)$, endothelin-1 $\mathrm{ET}_{\mathrm{A}}$ and $\mathrm{ET}_{\mathrm{B}}$ receptors (107). Administration of $5-\mathrm{HT}_{4}$ agonists such as metoclopramide, cisapride and tegaserod resulted in higher stimulation of aldosterone $(99,103,108)$. Nonspecific inhibitors of 5 -HT such as 
cyproheptadine and ketanserin produced only minor and transient inhibition of aldosterone secretion in aldosteronomas $(109,110)$. Specific $5-\mathrm{HT}_{4} \mathrm{R}$ antagonists such as GR 113808 are potent inhibitors of basal and cisaprideinduced aldosterone secretion (103). Chromaffin cells, endothelial cells, nerve terminals and cells of the immune system are localized in the immediate vicinity of zona glomerulosa cells and can secrete various factors to control aldosterone secretion (111). Local release of 5-HT by perivascular mast cells (MC) can activate $5-\mathrm{HT}_{4} \mathrm{R}$ expressed in zona glomerulosa cells and consequently stimulate aldosterone production (112). A role of MC in tumorigenesis was proposed $(113,114)$. The density of MC was found to be increased in APA tissues compared with normal adrenals. Immunohistochemistry showed that adrenal MC were tryptase positive and chymase negative. They were primarily observed in adrenal cortex adjacent to adenomas or in the adenomas themselves (115). Using a microarray approach in ten aldosteronomas compared with five normal adrenals and 13 cortisol-secreting adenomas, the six GCPRs with the highest increase in expression included LHCGR, 5- $\mathrm{HT}_{4} \mathrm{R}, \mathrm{GnRHR}$, glutamate receptor metabotropic three, endothelin receptor $\mathrm{ET}_{\mathrm{B}}$ receptors and MC2R (101).

Renin-independent stimulation of aldosterone secretion was observed in vivo following mixed meal, oral glucose, or administration of GIP, vasopressin and tegaserod in a patient with unilateral source of PA (116). Aldosterone secretion was stimulated by GIP in primary cultures of this patient's aldosteronoma. Real-time RT-PCR and immunohistochemistry found increased expression of GIPR as well as $5-\mathrm{HT}_{4} \mathrm{R}$ and MC2R were also present $(116,117)$. In a patient with BMAH and $\beta$-AR-aberrant expression, isoproterenol stimulated both cortisol and aldosterone production (117). A case of PA diagnosed during pregnancy appeared to correlate with aberrant LHR and GNRHR expression (118). To date, no extensive studies compared aberrant expression of GPCR in patients with APA to those with IHA. However, in the study by Zwermann et al. (99), of 12 cases of PA including five aldosteronomas and seven bilateral idiopathic aldosteronism (IHA), both subtypes presented aberrant response as 11 had increased response to metoclopramide, three patients had aberrant response to GnRH, six to vasopressin and one each to TRH and glucagons. The expression levels of several aberrant receptors including AT-1R, MC2R, AVPR1, HTR4, LHCGR, GnRH and TRHR using quantitative PCR were highly variable between each resected adrenal adenoma (99). Aberrant GPCR was also expressed in androgen-producing adrenal tumors and hyperplasias, mainly GIPR (119), LHCGR $(64,120,121)$ and $5-\mathrm{HT}_{4} \mathrm{R}(64)$.

\section{Aberrant receptors in CD and other endocrine tumors}

The concept of aberrant hormone receptors has become quite familiar in primary adrenal tumors, but in fact modifications of expression of several receptors and their effects on the regulation of secretion exist in many other endocrine tumors. In $\mathrm{CD}$, a high proportion of corticotroph tumors express the vasopressin-3 receptor (AVPR1b) ectopically and overexpress AVPR2 and respond to desmopressin (DDAVP) in vitro and in vivo(122). In 29 patients with $\mathrm{CD}$, most of the tumors exhibited abundant expression of AVPR1a, AVPR1b and CRHR, whereas the expression of AVPR2 varied greatly and was lower in macroadenomas than in microadenomas. After adjustment for tumor volume, a positive correlation was found between the percentage increment of ACTH and the degree of AVPR2 expression, but not between that of AVPR1 or AVPR1b. No relationship was observed between the level of CRHR expression in tumor tissues and the percentage increment or net AUC of ACTH to CRH administration in CD patients (123). Luque et al. evaluated a total of eight normal pituitaries (NPs), 23 corticotropinomas, 14 non-functioning pituitary adenomas, 17 somatotropinomas and three prolactinomas for AVPR expression; corticotropinomas variably expressed all AVPR subtypesAVPR1b being the predominant subtype followed by AVPR2 > AVPR1a. AVPR1b was significantly more expressed in corticotropinomas than in NPs. The use of an AVPR1b antagonist completely blocked DDAVP stimulatory effects. Remarkably, only AVPR1b expression was positively correlated with elevated plasma ACTH levels in corticotropinomas (124). Patients with CD respond aberrantly to ghrelin and hexarelin with increased ACTH secretion (125); the expression of ghrelin receptors, GHSR1a and GHS-R1b, in tumor tissue samples from two patients with CD were demonstrated. Ghrelin was found to be expressed in this same tissue and its ultrastructural immunolocalization within secretory granules supports the hypothesis that ghrelin can influence corticotropinoma cell function through an autocrine/ paracrine mechanism (126).

Epidermal growth factor receptor (EGFR) is frequently overexpressed in CD tumors, and in animal models the EGFR tyrosine kinase inhibitor gefitinib inhibited corticotroph tumor growth and clinical or biochemical features of CS (127). Recently, the mechanism of EGFR 
overexpression in $\mathrm{CD}$ was identified as somatic mutations in ubiquitin-specific peptidase 8 gene (USP8) were found in $35-62 \%$ of corticotroph adenomas from patients who had smaller but relatively more active tumors than those without USP8 mutations $(128,129)$. Inactivation of USP8 led to enhanced EGFR deubiquitination, impairing its downregulation, increasing epidermal growth factor signaling and POMC/ACTH synthesis that was suppressed by the EGFR inhibitor gefitinib $(128,129)$.

Other endocrine tumors harbored ectopic GPCR, including pheochromocytomas in which ectopic expression of glucagon receptor and HTR4 were demonstrated $(130,131)$. A female patient with pheochromocytoma experienced a life-threatening hypertension crisis after metoclopramide administration. Her tumor as well as 17 additional pheochromocytomas (nine benign and eight malignant) were studied in vitro. Metoclopramide and cisapride were found to activate catecholamine- and granin-derived peptide secretions by cultured tumor cells. These secretions were inhibited by the HTR4 antagonist GR 113808. HTR4 mRNAs were detected in the patient's tumor and the series of 17 additional pheochromocytomas (131). Based on a microarray analysis of phechromocytoma subtypes, both adrenal cortex and medullary tumor tissues and two adrenal tumor cell lines (PC-12 and SW-13) expressed receptors for somatostatin, GHRH, or the SV-1 splice variant, as well as for GnRH. The immunohistochemical staining of adrenal tissue showed strong staining for sst2 in normal adrenal cortex, adrenocortical adenoma and carcinoma, as well as in the SW-13 adrenocortical cell line. In adrenal medulla tumors, both benign and malignant specimens were moderately positive for sst2, as were PC-12 cells; however, no sst2 staining could be detected in the normal adrenal medulla (132). A somatostatin octapeptide RC-160 significantly reduced growth and survival of SW-13 human adrenocortical cells under proliferative culture conditions. Similar results were seen with the use of GHRH antagonist MZ-471 and LHRH antagonist Cetrorelix (132). In acromegaly the presence of ectopic TRH, GnRH or GIP receptors explains the frequently observed paradoxical increase in GH after administration of TRH, GnRH or oral glucose respectively $(133,134,135,136,137,138)$. GIPR expression was investigated in 43 somatotropinomas and 12 normal pituitary glands by quantitative RT-PCR, western blotting and immunohistochemistry. GIPR was expressed at higher levels compared to NPs in 13 GNAS1 mutation-negative somatotropinomas. GIP stimulated adenylyl cyclase and GH-promoter activity in GIPRtransfected GH3 cells, confirming a correct coupling of
GIPR to Gas (134). A 39-year-old woman with a confirmed diagnosis of acromegaly had an ACTH response to DDAVP (plasma ACTH levels increased from 13.9 to $50.4 \mathrm{pg} / \mathrm{ml}$ at $90 \mathrm{~min}$ ). After transsphenoidal resection of the pituitary tumor, immunohistological examination confirmed a GH and PRL-producing adenoma, whereas ACTH was negative. ACTH response to DDAVP disappeared after tumor removal. To determine the cause of preoperative ACTH response to DDAVP, the expression of corticotropin-releasing factor (CRF) family peptides and vasopressin $\mathrm{V} 1 \mathrm{~b}$ receptor in the pituitary adenoma was examined by immunohistochemistry. Immunohistochemistry revealed positive immunostaining for CRF, urocoritn1 (Ucn1), urocortin3 (Ucn3) and vasopressin $\mathrm{V} 1 \mathrm{~b}$ receptor in the adenoma. These observations raised the possibility that DDAVP caused an ACTH response, perhaps via the paracrine effects of tumor-derived CRF and Ucn1 (139).

\section{Could targeted medical therapy become useful for adrenal tumors and hyperplasia?}

Surgery is the current recommended therapy for BMAH: bilateral adrenalectomy for severe disease with lifelong cortisol/fludrocortisone replacement vs unilateral adrenalectomy for milder disease (urinary free cortisol less than two times the upper limit of normal) with resection of the larger gland or the functionally more active. For nonsurgical candidates, inhibiting adrenal steroidogenesis by ketoconazole or metyrapone remains a valid option with a drawback of many adverse events such as liver toxicity and hypertension. Annual evaluation for subclinical disease with close monitoring of blood glucose, blood pressure control and osteoporosis is indicated (44). To date, no large prospective randomized trials followed patients with SCS with aberrant hormone responses to evaluate the rate of progression to overt CS. Recently, Albiger et al. reported on the follow-up of 16 patients with BMAH and CS: one case with food-dependent CS was treated with octreotide LAR and two patients with a positive postural test were treated with propranolol. Limited clinical response was noted despite marked improvement in biochemical values in all three patients. Twelve patients underwent unilateral adrenalectomy, with long-term remission in three, recurrence in eight and persistence in one other. Four patients subsequently needed contralateral adrenalectomy for overt CS, one received ketoconazole and four other patients remain under surveillance for SCS (140).

The concept of regulation of steroidogenesis by aberrant GPCR expression and by the paracrine/autocrine 
production of their ligands offered the possibility of targeted therapy using specific receptor-targeted peptide antagonists (Table 2). $\beta$-blockers and leuprolide acetate achieved long-term control of BMAH in $\beta$-AR and LH/hCGR dependent hypercortisolism respectively (41, $64,117,141)$. Octreotide or pasireotide resulted in shortterm control in a BMAH patient with aberrant expression of GIPR presumably because GIP suppression escapes as downregulation of somatostatin receptors in $\mathrm{K}$ cells occurs during chronic administration of the long-acting agonists $(41,142,143)$. Administration of antagonists of V1aR, AT1R or $\beta$-AR reduced cortisol levels in patients with aberrant response to upright posture $(144,145,146)$. ACTH-receptor antagonists significantly inhibited cortisol secretion in vitro in perifused BMAH tissues from patients with abnormal plasma cortisol responses to GIP because GIPR activation partially stimulated cortisol secretion by stimulating ACTH secretion in a paracrine way to control cortisol synthesis (34). As CS is relatively rare, the development of specific antagonists for the more frequent aberrant GPCR such as AVPR1 or HTR4 have been lacking; considering the high prevalence of SCS cases with BMAH or unilateral incidentaloma, or of PA with their increased cardiovascular morbidity, it is hoped that the development of antagonists for the aberrant receptors could become more appealing to the pharmaceutical industry.

\section{Conclusions and Perspectives}

In recent years, growing evidence has shown that in a significant proportion of adrenal tumors or hyperplasia steroidogenesis is not constitutive but is rather regulated by aberrant GPCR and their ligands. Whether the aberrant GPCR expression is the initiating event or the consequence of a proliferative event leading to adrenal hyperplasia or tumorigenesis is still debatable. It was shown that a single genetic event, inappropriate expression of a nonmutated GPCR gene, is sufficient to initiate the complete phenotypic alterations that ultimately lead to the formation of a benign adrenocortical tumors in animal models (63). The recent demonstration of ARMC5 mutations in BMAH rather supports the notion that aberrant expression of one or several GPCR and of their ligands in adrenal tissues is a secondary rather than a primary event $(27,30,147)$. Similarly, in a subset of CD patients, USP8 mutations are responsible for the aberrant overexpression of EGFR (128). Rare intriguing cases, however, support their initiating role in tumorigenesis as illustrated by the study of a 22-year-old woman who presented with two transient pregnancy-induced severe CS and spontaneous resolution of CS and adrenal hyperplasia after preterm parturition. Stimulation with exogenous hCG induced hypercortisolism. Bilateral adrenalectomy showed normal adrenal histology. In vitro adrenal LHR-expression and activation was found (148).

Further studies are needed to uncover the link between aberrant receptors and germline mutations of ARMC5 in BMAH or somatic mutations of ion channels in PA or of PRKACA in cortisol secreting adenomas. Future work will probably identify a larger diversity of aberrant GPCRs not only in adrenal tumors, but also in other endocrine and non-endocrine tissues. Autocrine/paracrine secretion of peptides and aberrant receptors in adrenocortical tissues/tumors/hyperplasia or other endocrine tumors offer promising specific targeted medical options as well as potential utility in imaging with specific ligands as suggested by the use of serotonin receptor-based PET scan to identify lateralization of dominant tumor in PA (149).

Declaration of interest

There is no conflict of interest that could be perceived as prejudicing the impartiality of the review.

\section{Funding}

This research received partial funding from the Canadian Institutes of Health Research (CIHR) grant number 201209NMD to A Lacroix and I Bourdeau. I Bourdeau receives partial salary support from the Fonds de la Recherche du Québec-Santé. N El Ghorayeb receives partial fellowship salary support from Novartis Canada.

Author contribution statement

Each author contributed to the design, writing and revision of this review article.

\section{Acknowledgements}

The authors wish to acknowledge Mr Bruno St-Pierre for his contribution to the preparation of Fig. 1.

This paper forms part of a special issue of European Journal of Endocrinology on Cushing's syndrome. This article is adapted from work presented at the IMPROCUSH-1: Improving Outcome of Cushing's Syndrome symposium, 12-14 October 2014. The meeting was supported by the European Science Foundation, Deutsche Forschungsgemeinschaft, Carl Friedrich von Siemens Stiftung, European Neuroendocrine Association and the Deutsche Gesellschaft für Endokrinologie. The opinions or views expressed in this special issue are those of the authors, and do not necessarily reflect the opinions or recommendations of the European Science Foundation, Deutsche Forschungsgemeinschaft, Carl Friedrich von Siemens Stiftung, European Neuroendocrine Association and the Deutsche Gesellschaft für Endokrinologie. 


\section{References}

1 Newell-Price J, Bertagna X, Grossman AB \& Nieman LK. Cushing's syndrome. Lancet 2006367 1605-1617. (doi:10.1016/S0140-6736 (06)68699-6)

2 Lacroix A, Feelders RA, Stratakis CE \& Niemann LK. Cushing's syndrome. Lancet. 2015 In press. (doi:10.1016/S0140-6736(14)61375-1)

3 Chiodini I. Clinical review: diagnosis and treatment of subclinical hypercortisolism. Journal of Clinical Endocrinology and Metabolism 2011 96 1223-1236. (doi:10.1210/jc.2010-2722)

4 Chan LF, Metherell LA \& Clark AJ. Effects of melanocortins on adrenal gland physiology. European Journal of Pharmacology 2011660 171-180. (doi:10.1016/j.ejphar.2010.11.041)

5 de Joussineau C, Sahut-Barnola I, Levy I, Saloustros E, Val P, Stratakis CA \& Martinez A. The cAMP pathway and the control of adrenocortical development and growth. Molecular and Cellular Endocrinology 2012351 28-36. (doi:10.1016/j.mce.2011.10.006)

6 Pearce LR, Komander D \& Alessi DR. The nuts and bolts of AGC protein kinases. Nature Reviews. Molecular Cell Biology 201011 9-22. (doi:10.1038/nrm2822)

7 Lacroix A, Ndiaye N, Tremblay J \& Hamet P. Ectopic and abnormal hormone receptors in adrenal Cushing's syndrome. Endocrine Reviews 200122 75-110. (doi:10.1210/edrv.22.1.0420)

8 Beuschlein F, Fassnacht M, Assie G, Calebiro D, Stratakis CA, Osswald A, Ronchi CL, Wieland T, Sbiera S, Faucz FR et al. Constitutive activation of PKA catalytic subunit in adrenal Cushing's syndrome. New England Journal of Medicine 2014370 1019-1028. (doi:10.1056/ NEJMoa1310359)

9 Di Dalmazi G, Kisker C, Calebiro D, Mannelli M, Canu L, Arnaldi G, Quinkler M, Rayes N, Tabarin A, Laure Jullie M et al. Novel somatic mutations in the catalytic subunit of the protein kinase A as a cause of adrenal Cushing's syndrome: a European multicentric study. Journal of Clinical Endocrinology and Metabolism 201499 E2093-2100. (doi:10.1210/jc.2014-2152)

10 Cao Y, He M, Gao Z, Peng Y, Li Y, Li L, Zhou W, Li X, Zhong X, Lei Y et al. Activating hotspot L205R mutation in PRKACA and adrenal Cushing's syndrome. Science 2014344 913-917. (doi:10.1126/science. 1249480)

11 Goh G, Scholl UI, Healy JM, Choi M, Prasad ML, Nelson-Williams C, Kunstman JW, Korah R, Suttorp AC, Dietrich D et al. Recurrent activating mutation in PRKACA in cortisol-producing adrenal tumors. Nature Genetics 201446 613-617. (doi:10.1038/ng.2956)

12 Sato Y, Maekawa S, Ishii R, Sanada M, Morikawa T, Shiraishi Y, Yoshida K, Nagata Y, Sato-Otsubo A, Yoshizato T et al. Recurrent somatic mutations underlie corticotropin-independent Cushing's syndrome. Science 2014344 917-920. (doi:10.1126/science.1252328)

13 Groussin L, Jullian E, Perlemoine K, Louvel A, Leheup B, Luton JP, Bertagna X \& Bertherat J. Mutations of the PRKAR1A gene in Cushing's syndrome due to sporadic primary pigmented nodular adrenocortical disease. Journal of Clinical Endocrinology and Metabolism 200287 4324-4329. (doi:10.1210/jc.2002-020592)

14 Groussin L, Kirschner LS, Vincent-Dejean C, Perlemoine K, Jullian E, Delemer B, Zacharieva S, Pignatelli D, Carney JA, Luton JP et al. Molecular analysis of the cyclic AMP-dependent protein kinase A (PKA) regulatory subunit 1A (PRKAR1A) gene in patients with Carney complex and primary pigmented nodular adrenocortical disease (PPNAD) reveals novel mutations and clues for pathophysiology: augmented PKA signaling is associated with adrenal tumorigenesis in PPNAD. American Journal of Human Genetics 200271 1433-1442. (doi:10.1086/344579)

15 Groussin L, Horvath A, Jullian E, Boikos S, Rene-Corail F, Lefebvre H, Cephise-Velayoudom FL, Vantyghem MC, Chanson P, ConteDevolx B et al. A PRKAR1A mutation associated with primary pigmented nodular adrenocortical disease in 12 kindreds. Journal of
Clinical Endocrinology and Metabolism 200691 1943-1949. (doi:10.1210/jc.2005-2708)

16 Kirschner LS, Carney JA, Pack SD, Taymans SE, Giatzakis C, Cho YS, Cho-Chung YS \& Stratakis CA. Mutations of the gene encoding the protein kinase A type I- $\alpha$ regulatory subunit in patients with the Carney complex. Nature Genetics 200026 89-92. (doi:10.1038/79238)

17 Horvath A, Boikos S, Giatzakis C, Robinson-White A, Groussin L, Griffin KJ, Stein E, Levine E, Delimpasi G, Hsiao HP et al. A genomewide scan identifies mutations in the gene encoding phosphodiesterase 11A4 (PDE11A) in individuals with adrenocortical hyperplasia. Nature Genetics 200638 794-800. (doi:10.1038/ng1809)

18 Rothenbuhler A, Horvath A, Libe R, Faucz FR, Fratticci A, Raffin Sanson ML, Vezzosi D, Azevedo M, Levy I, Almeida MQ et al. Identification of novel genetic variants in phosphodiesterase $8 \mathrm{~B}$ (PDE8B), a cAMP-specific phosphodiesterase highly expressed in the adrenal cortex, in a cohort of patients with adrenal tumours. Clinical Endocrinology 201277 195-199. (doi:10.1111/j.1365-2265.2012. 04366.x)

19 Mauras N \& Blizzard RM. The McCune-Albright syndrome. Acta Endocrinologica. Supplementum 1986279 207-217.

20 Spiegel AM \& Weinstein LS. Inherited diseases involving G proteins and G protein-coupled receptors. Annual Review of Medicine 200455 27-39. (doi:10.1146/annurev.med.55.091902.103843)

21 Fragoso MC, Domenice S, Latronico AC, Martin RM, Pereira MA, Zerbini MC, Lucon AM \& Mendonca BB. Cushing's syndrome secondary to adrenocorticotropin-independent macronodular adrenocortical hyperplasia due to activating mutations of GNAS1 gene. Journal of Clinical Endocrinology and Metabolism 200388 2147-2151. (doi:10.1210/jc.2002-021362)

22 Brown RJ, Kelly MH \& Collins MT. Cushing syndrome in the McCuneAlbright syndrome. Journal of Clinical Endocrinology and Metabolism 201095 1508-1515. (doi:10.1210/jc.2009-2321)

23 Latronico AC, Reincke M, Mendonca BB, Arai K, Mora P, Allolio B, Wajchenberg BL, Chrousos GP \& Tsigos C. No evidence for oncogenic mutations in the adrenocorticotropin receptor gene in human adrenocortical neoplasms. Journal of Clinical Endocrinology and Metabolism 199580 875-877. (doi:10.1210/jcem.80.3.7883845)

24 Light K, Jenkins PJ, Weber A, Perrett C, Grossman A, Pistorello M, Asa SL, Clayton RN \& Clark AJ. Are activating mutations of the adrenocorticotropin receptor involved in adrenal cortical neoplasia? Life Sciences 199556 1523-1527. (doi:10.1016/0024-3205(95)00114-L)

25 Swords FM, Baig A, Malchoff DM, Malchoff CD, Thorner MO, King PJ, Hunyady L \& Clark AJ. Impaired desensitization of a mutant adrenocorticotropin receptor associated with apparent constitutive activity. Molecular Endocrinology 2002 16 2746-2753. (doi:10.1210/me. 2002-0099)

26 Swords FM, Noon LA, King PJ \& Clark AJ. Constitutive activation of the human ACTH receptor resulting from a synergistic interaction between two naturally occurring missense mutations in the MC2R gene. Molecular and Cellular Endocrinology 2004213 149-154. (doi:10.1016/j.mce.2003.10.052)

27 Alencar GA, Lerario AM, Nishi MY, Mariani BM, Almeida MQ, Tremblay J, Hamet P, Bourdeau I, Zerbini MC, Pereira MA et al. ARMC5 mutations are a frequent cause of primary macronodular adrenal hyperplasia. Journal of Clinical Endocrinology and Metabolism 201499 E1501-E1509. (doi:10.1210/jc.2013-4237)

28 Faucz FR, Zilbermint M, Lodish MB, Szarek E, Trivellin G, Sinaii N, Berthon A, Libe R, Assie G, Espiard S et al. Macronodular adrenal hyperplasia due to mutations in an armadillo repeat containing 5 (ARMC5) gene: a clinical and genetic investigation. Journal of Clinical Endocrinology and Metabolism 201499 E1113-E1119. (doi:10.1210/ jc.2013-4280)

29 Gagliardi L, Schreiber AW, Hahn CN, Feng J, Cranston T, Boon H, Hotu C, Oftedal BE, Cutfield R, Adelson DL et al. ARMC5 mutations are common in familial bilateral macronodular adrenal hyperplasia. 
Journal of Clinical Endocrinology and Metabolism 201499 E1784-E1792. (doi:10.1210/jc.2014-1265)

30 Assie G, Libe R, Espiard S, Rizk-Rabin M, Guimier A, Luscap W, Barreau O, Lefevre L, Sibony M, Guignat L et al. ARMC5 mutations in macronodular adrenal hyperplasia with Cushing's syndrome. New England Journal of Medicine 2013369 2105-2114. (doi:10.1056/ NEJMoa1304603)

31 Espiard S, Drougat L, Libe R, Assie G, Perlemoine K, Guignat L, Barrande G, Brucker-Davis F, Doullay F, Lopez S et al. ARMC5 mutations in a large cohort of primary macronodular adrenal hyperplasia: clinical and functional consequences. Journal of Clinical Endocrinology and Metabolism 2015100 E926-E930. (doi:10.1210/jc. 2014-4204)

32 Lee S, Hwang R, Lee J, Rhee Y, Kim DJ, Chung UI \& Lim SK. Ectopic expression of vasopressin $\mathrm{V} 1 \mathrm{~b}$ and $\mathrm{V} 2$ receptors in the adrenal glands of familial ACTH-independent macronodular adrenal hyperplasia. Clinical Endocrinology 200563 625-630. (doi:10.1111/j.1365-2265. 2005.02387.x)

33 Elbelt U, Trovato A, Kloth M, Gentz E, Finke R, Spranger J, Galas D, Weber S, Wolf C, Konig K et al. Molecular and clinical evidence for an ARMC5 tumor syndrome: concurrent inactivating germline and somatic mutations are associated with both primary macronodular adrenal hyperplasia and meningioma. Journal of Clinical Endocrinology and Metabolism 2015100 E119-E128. (doi:10.1210/jc.2014-2648)

34 Louiset E, Duparc C, Young J, Renouf S, Tetsi Nomigni M, Boutelet I, Libe R, Bram Z, Groussin L, Caron P et al. Intraadrenal corticotropin in bilateral macronodular adrenal hyperplasia. New England Journal of Medicine 2013369 2115-2125. (doi:10.1056/NEJMoa1215245)

35 Lefebvre H, Duparc C, Prevost G, Zennaro MC, Bertherat J \& Louiset E. Paracrine control of steroidogenesis by serotonin in adrenocortical neoplasms. Molecular and Cellular Endocrinology 2015408 198-204. (doi:10.1016/j.mce.2014.11.013)

36 Schorr I \& Ney RL. Abnormal hormone responses of an adrenocortical cancer adenyl cyclase. Journal of Clinical Investigation $1971 \mathbf{5 0}$ 1295-1300. (doi:10.1172/JCI106608)

37 Hamet P, Larochelle P, Franks DJ, Cartier P \& Bolte E. Cushing syndrome with food-dependent periodic hormonogenesis. Clinical and Investigative Medicine 198710 530-533.

38 Lacroix A, Bolte E, Tremblay J, Dupre J, Poitras P, Fournier H, Garon J, Garrel D, Bayard F \& Taillefer R. Gastric inhibitory polypeptidedependent cortisol hypersecretion - a new cause of Cushing's syndrome. New England Journal of Medicine 1992327 974-980. (doi:10.1056/NEJM199210013271402)

39 Reznik Y, Allali-Zerah V, Chayvialle JA, Leroyer R, Leymarie P, Travert G, Lebrethon MC, Budi I, Balliere AM \& Mahoudeau J. Food-dependent Cushing's syndrome mediated by aberrant adrenal sensitivity to gastric inhibitory polypeptide. New England Journal of Medicine 1992327 981-986. (doi:10.1056/NEJM1992100 13271403)

40 Lacroix A, Baldacchino V, Bourdeau I, Hamet P \& Tremblay J. Cushing's syndrome variants secondary to aberrant hormone receptors. Trends in Endocrinology and Metabolism 200415 375-382. (doi:10.1016/S1043-2760(04)00188-2)

41 Lacroix A, Bourdeau I, Lampron A, Mazzuco TL, Tremblay J \& Hamet P. Aberrant G-protein coupled receptor expression in relation to adrenocortical overfunction. Clinical Endocrinology 201073 1-15. (doi:10.1111/j.1365-2265.2009.03689.x)

42 Lacroix A \& Bourdeau I. Bilateral adrenal Cushing's syndrome: macronodular adrenal hyperplasia and primary pigmented nodular adrenocortical disease. Endocrinology and Metabolism Clinics of North America 200534 441-458, x. (doi:10.1016/j.ecl.2005.01.004)

43 Mermejo LM, Mazzuco TL, Grunenwald S, Fragoso MC, Bourdeau I \& Lacroix A. ACTH-independent macronodular adrenal hyperplasia. Endocrinology and Metabolism 201126 1. (doi:10.3803/EnM.2011. 26.1.1)
44 Lacroix A. ACTH-independent macronodular adrenal hyperplasia. Best Practice \& Research. Clinical Endocrinology \& Metabolism 200923 245-259. (doi:10.1016/j.beem.2008.10.011)

45 Mircescu H, Jilwan J, N'Diaye N, Bourdeau I, Tremblay J, Hamet P \& Lacroix A. Are ectopic or abnormal membrane hormone receptors frequently present in adrenal Cushing's syndrome? Journal of Clinical Endocrinology and Metabolism 200085 3531-3536. (doi:10.1210/jcem. 85.10.6865)

46 Reznik Y, Lefebvre H, Rohmer V, Charbonnel B, Tabarin A, Rodien P, Lecomte P, Bardet S, Coffin C, Mahoudeau J et al. Aberrant adrenal sensitivity to multiple ligands in unilateral incidentaloma with subclinical autonomous cortisol hypersecretion: a prospective clinical study. Clinical Endocrinology 200461 311-319. (doi:10.1111/j.13652265.2004.02048.x)

47 Libe R, Coste J, Guignat L, Tissier F, Lefebvre H, Barrande G, Ajzenberg C, Tauveron I, Clauser E, Dousset B et al. Aberrant cortisol regulations in bilateral macronodular adrenal hyperplasia: a frequent finding in a prospective study of 32 patients with overt or subclinical Cushing's syndrome. European Journal of Endocrinology 2010163 129-138. (doi:10.1530/EJE-10-0195)

48 Hofland J, Hofland LJ, van Koetsveld PM, Steenbergen J, de Herder WW, van Eijck CH, de Krijger RR, van Nederveen FH, van Aken MO, de Groot JW et al. ACTH-independent macronodular adrenocortical hyperplasia reveals prevalent aberrant in vivo and in vitro responses to hormonal stimuli and coupling of argininevasopressin type 1a receptor to 11ß-hydroxylase. Orphanet Journal of Rare Diseases 20138 142. (doi:10.1186/1750-1172-8-142)

49 Hsiao HP, Kirschner LS, Bourdeau I, Keil MF, Boikos SA, Verma S, Robinson-White AJ, Nesterova M, Lacroix A \& Stratakis CA. Clinical and genetic heterogeneity, overlap with other tumor syndromes, and atypical glucocorticoid hormone secretion in adrenocorticotropinindependent macronodular adrenal hyperplasia compared with other adrenocortical tumors. Journal of Clinical Endocrinology and Metabolism 200994 2930-2937. (doi:10.1210/jc.2009-0516)

50 Bourdeau I, D'Amour P, Hamet P, Boutin JM \& Lacroix A. Aberrant membrane hormone receptors in incidentally discovered bilateral macronodular adrenal hyperplasia with subclinical Cushing's syndrome. Journal of Clinical Endocrinology and Metabolism 200186 5534-5540. (doi:10.1210/jcem.86.11.8062)

51 Tatsuno I, Uchida D, Tanaka T, Koide H, Shigeta A, Ichikawa T, Sasano H \& Saito Y. Vasopressin responsiveness of subclinical Cushing's syndrome due to ACTH-independent macronodular adrenocortical hyperplasia. Clinical Endocrinology 200460 192-200. (doi:10.1046/j.1365-2265.2003.01963.x)

52 Dall'Asta C, Ballare E, Mantovani G, Ambrosi B, Spada A, Barbetta L, Colombo P, Travaglini P, Loli P \& Beck-Peccoz P. Assessing the presence of abnormal regulation of cortisol secretion by membrane hormone receptors: in vivo and in vitro studies in patients with functioning and non-functioning adrenal adenoma. Hormone and Metabolic Research 200436 578-583. (doi:10.1055/s-2004-825797)

53 Joubert M, Louiset E, Rego JL, Contesse V, Kong LC, Benhaim A, Mittre H, Lefebvre H, Reznik Y \& Group RS. Aberrant adrenal sensitivity to vasopressin in adrenal tumours associated with subclinical or overt autonomous hypercortisolism: is this explained by an overexpression of vasopressin receptors? Clinical Endocrinology 2008 68 692-699. (doi:10.1111/j.1365-2265.2007.03106.x)

54 Albiger NM, Occhi G, Mariniello B, Iacobone M, Favia G, Fassina A, Faggian D, Mantero F \& Scaroni C. Food-dependent Cushing's syndrome: from molecular characterization to therapeutical results. European Journal of Endocrinology 2007157 771-778. (doi:10.1530/EJE07-0253)

55 Bertherat J, Contesse V, Louiset E, Barrande G, Duparc C, Groussin L, Emy $\mathrm{P}$, Bertagna $\mathrm{X}, \mathrm{Kuhn} \mathrm{JM}$, Vaudry $\mathrm{H}$ et al. In vivo and in vitro screening for illegitimate receptors in adrenocorticotropin-independent macronodular adrenal hyperplasia causing Cushing's syndrome: identification of two cases of gonadotropin/gastric inhibitory 
polypeptide-dependent hypercortisolism. Journal of Clinical Endocrinology and Metabolism 200590 1302-1310. (doi:10.1210/ jc.2004-1256)

56 Lampron A, Bourdeau I, Hamet P, Tremblay J \& Lacroix A. Whole genome expression profiling of glucose-dependent insulinotropic peptide (GIP)- and adrenocorticotropin-dependent adrenal hyperplasias reveals novel targets for the study of GIP-dependent Cushing's syndrome. Journal of Clinical Endocrinology and Metabolism 200691 3611-3618. (doi:10.1210/jc.2006-0221)

57 N'Diaye N, Hamet P, Tremblay J, Boutin JM, Gaboury L \& Lacroix A. Asynchronous development of bilateral nodular adrenal hyperplasia in gastric inhibitory polypeptide-dependent cushing's syndrome. Journal of Clinical Endocrinology and Metabolism 199984 2616-2622. (doi:10.1210/jcem.84.8.5930)

58 Chabre O, Liakos P, Vivier J, Bottari S, Bachelot I, Chambaz EM, Feige JJ \& Defaye G. Gastric inhibitory polypeptide (GIP) stimulates cortisol secretion, cAMP production and DNA synthesis in an adrenal adenoma responsible for food-dependent Cushing's syndrome. Endocrine Research 199824 851-856. (doi:10.3109/ 07435809809032696)

59 Swords FM, Aylwin S, Perry L, Arola J, Grossman AB, Monson JP \& Clark AJ. The aberrant expression of the gastric inhibitory polypeptide (GIP) receptor in adrenal hyperplasia: does chronic adrenocorticotropin exposure stimulate up-regulation of GIP receptors in Cushing's disease? Journal of Clinical Endocrinology and Metabolism 2005903009 3016. (doi:10.1210/jc.2004-0946)

60 Antonini SR, Baldacchino V, Tremblay J, Hamet P \& Lacroix A Expression of ACTH receptor pathway genes in glucose-dependent insulinotrophic peptide (GIP)-dependent Cushing's syndrome. Clinical Endocrinology 200664 29-36. (doi:10.1111/j.1365-2265.2005. 02411.x)

61 Baldacchino V, Oble S, Decarie PO, Bourdeau I, Hamet P, Tremblay J \& Lacroix A. The Sp transcription factors are involved in the cellular expression of the human glucose-dependent insulinotropic polypeptide receptor gene and overexpressed in adrenals of patients with Cushing's syndrome. Journal of Molecular Endocrinology 200535 61-71. (doi:10.1677/jme.1.01765)

62 N'Diaye N, Tremblay J, Hamet P, De Herder WW \& Lacroix A. Adrenocortical overexpression of gastric inhibitory polypeptide receptor underlies food-dependent Cushing's syndrome. Journal of Clinical Endocrinology and Metabolism 199883 2781-2785. (doi:10.1210/jcem.83.8.5038)

63 Mazzuco TL, Chabre O, Sturm N, Feige JJ \& Thomas M. Ectopic expression of the gastric inhibitory polypeptide receptor gene is a sufficient genetic event to induce benign adrenocortical tumor in a xenotransplantation model. Endocrinology 2006147 782-790. (doi:10.1210/en.2005-0921)

64 Lacroix A, Hamet P \& Boutin JM. Leuprolide acetate therapy in luteinizing hormone-dependent Cushing's syndrome. New England Journal of Medicine 1999341 1577-1581. (doi:10.1056/ NEJM199911183412104)

65 Chui MH, Ozbey NC, Ezzat S, Kapran Y, Erbil Y \& Asa SL. Case report: adrenal LH/hCG receptor overexpression and gene amplification causing pregnancy-induced Cushing's syndrome. Endocrine Pathology 200920 256-261. (doi:10.1007/s12022-009-9090-2)

66 Feelders RA, Lamberts SW, Hofland LJ, van Koetsveld PM, VerhoefPost M, Themmen AP, de Jong FH, Bonjer HJ, Clark AJ, van der Lely AJ et al. Luteinizing hormone (LH)-responsive Cushing's syndrome: the demonstration of LH receptor messenger ribonucleic acid in hyperplastic adrenal cells, which respond to chorionic gonadotropin and serotonin agonists in vitro. Journal of Clinical Endocrinology and Metabolism 200388 230-237. (doi:10.1210/jc.2002-020621)

67 Bugalho MJ, Li X, Rao CV, Soares J \& Sobrinho LG. Presence of a Gs $\alpha$ mutation in an adrenal tumor expressing LH/hCG receptors and clinically associated with Cushing's syndrome. Gynecological Endocrinology 200014 50-54. (doi:10.3109/09513590009167660)
68 Kero J, Poutanen M, Zhang FP, Rahman N, McNicol AM, Nilson JH, Keri RA \& Huhtaniemi IT. Elevated luteinizing hormone induces expression of its receptor and promotes steroidogenesis in the adrenal cortex. Journal of Clinical Investigation 2000105 633-641. (doi:10.1172/JCI7716)

69 Assie G, Louiset E, Sturm N, Rene-Corail F, Groussin L, Bertherat J, Thomas M, Lefebvre H, Feige JJ, Clauser E et al. Systematic analysis of G protein-coupled receptor gene expression in adrenocorticotropinindependent macronodular adrenocortical hyperplasia identifies novel targets for pharmacological control of adrenal Cushing's syndrome. Journal of Clinical Endocrinology and Metabolism 201095 E253-E262. (doi:10.1210/jc.2009-2281)

70 Jaiswal N \& Sharma RK. Dual regulation of adenylate cyclase and guanylate cyclase: $\alpha 2$-adrenergic signal transduction in adrenocortical carcinoma cells. Archives of Biochemistry and Biophysics 1986249 616-619. (doi:10.1016/0003-9861(86)90041-X)

71 Louiset E, Isvi K, Gasc JM, Duparc C, Cauliez B, Laquerriere A, Kuhn JM \& Lefebvre H. Ectopic expression of serotonin7 receptors in an adrenocortical carcinoma co-secreting renin and cortisol. EndocrineRelated Cancer 200815 1025-1034. (doi:10.1677/ERC-08-0085)

72 Contesse V, Reznik Y, Louiset E, Duparc C, Cartier D, Sicard F, Laquerriere A, Parmentier F, Kuhn JM, Vaudry H et al. Abnormal sensitivity of cortisol-producing adrenocortical adenomas to serotonin: in vivo and in vitro studies. Journal of Clinical Endocrinology and Metabolism 200590 2843-2850. (doi:10.1210/jc.2004-2476)

73 Matsukura S, Kakita T, Sueoka S, Yoshimi H, Hirata Y, Yokota M \& Fujita T. Multiple hormone receptors in the adenylate cyclase of human adrenocortical tumors. Cancer Research 198040 3768-3771.

74 de Miguel V, Redal MA, Viale ML, Kahan M, Glerean M, Beskow A \& Fainstein Day P. Aberrant expression of glucagon receptors in adrenal glands of a patient with Cushing's syndrome and ACTH-independent macronodular adrenal hyperplasia. Medicina 201070 254-256.

75 Louiset E, Duparc C, Groussin L, Gobet F, Desailloud R, Barrande G, Reznik Y, Bertherat J, Prevost G \& Lefebvre H. Abnormal sensitivity to glucagon and related peptides in primary adrenal Cushing's syndrome. Hormone and Metabolic Research 201446 876-882. (doi:10.1055/s-0034-1384522)

76 Xekouki P, Bram Z, Louiset E, Avgeropoulos D, Nesterova MV, Sinaii N, Lefebvre $\mathrm{H} \&$ Stratakis CA. Expression of somatostatin receptors in normal adrenal and in primary pigmented nodular adrenocortical disease (PPNAD). A possible new use for somatostatin analogues. The Endocrine Society's 95th Annual Meeting and Expo, June 15-18, 2013 - San Francisco. Abstract, pp MON-8-MON-8.

77 Gagliardi L, Hotu C, Casey G, Braund WJ, Ling KH, Dodd T, Manavis J Devitt PG, Cutfield R, Rudzki Z et al. Familial vasopressin-sensitive ACTH-independent macronodular adrenal hyperplasia (VPs-AIMAH): clinical studies of three kindreds. Clinical Endocrinology 200970 883-891. (doi:10.1111/j.1365-2265.2008.03471.x)

78 Miyamura N, Taguchi T, Murata Y, Taketa K, Iwashita S, Matsumoto K, Nishikawa T, Toyonaga T, Sakakida M \& Araki E. Inherited adrenocorticotropin-independent macronodular adrenal hyperplasia with abnormal cortisol secretion by vasopressin and catecholamines: detection of the aberrant hormone receptors on adrenal gland. Endocrine 200219 319-326. (doi:10.1385/ENDO:19:3:319)

79 Vezzosi D, Cartier D, Regnier C, Otal P, Bennet A, Parmentier F, Plantavid M, Lacroix A, Lefebvre H \& Caron P. Familial adrenocorticotropin-independent macronodular adrenal hyperplasia with aberrant serotonin and vasopressin adrenal receptors. European Journal of Endocrinology 2007156 21-31. (doi:10.1530/eje.1.02324)

80 Findlay JC, Sheeler LR, Engeland WC \& Aron DC. Familial adrenocorticotropin-independent Cushing's syndrome with bilateral macronodular adrenal hyperplasia. Journal of Clinical Endocrinology and Metabolism 199376 189-191. (doi:10.1210/jcem.76.1.8380604)

81 Imohl M, Koditz R, Stachon A, Muller KM, Nicolas V, Pfeilschifter J \& Krieg M. Catecholamine-dependent hereditary Cushing's syndrome - 
follow-up after unilateral adrenalectomy. Medizinische Klinik 200297 747-753. (doi:10.1007/s00063-002-1220-2)

82 Minami S, Sugihara H, Sato J, Tatsukuchi A, Sugisaki Y, Sasano H \& Wakabayashi I. ACTH independent Cushing's syndrome occurring in siblings. Clinical Endocrinology 199644 483-488. (doi:10.1046/j.13652265.1996.682504.x)

83 Nies C, Bartsch DK, Ehlenz K, Wild A, Langer P, Fleischhacker S \& Rothmund M. Familial ACTH-independent Cushing's syndrome with bilateral macronodular adrenal hyperplasia clinically affecting only female family members. Experimental and Clinical Endocrinology \& Diabetes 2002110 277-283. (doi:10.1055/s-2002-34590)

84 Louiset E, Contesse V, Groussin L, Cartier D, Duparc C, Perraudin V, Bertherat J \& Lefebvre $\mathrm{H}$. Expression of vasopressin receptors in ACTH-independent macronodular bilateral adrenal hyperplasia causing Cushing's syndrome: molecular, immunohistochemical and pharmacological correlates. Journal of Endocrinology 2008196 1-9. (doi:10.1677/JOE-07-0413)

85 Cartier D, Lihrmann I, Parmentier F, Bastard C, Bertherat J, Caron P, Kuhn JM, Lacroix A, Tabarin A, Young J et al. Overexpression of serotonin 4 receptors in cisapride-responsive adrenocorticotropinindependent bilateral macronodular adrenal hyperplasia causing Cushing's syndrome. Journal of Clinical Endocrinology and Metabolism 200388 248-254. (doi:10.1210/jc.2002-021107)

86 Louiset E, Cartier D, Contesse V, Duparc C, Lihrmann I, Young J, Bertherat J, Reznik Y, Kuhn JM, Laquerriere A et al. Paradoxical inhibitory effect of serotonin on cortisol production from adrenocortical lesions causing Cushing's syndrome. Endocrine Research 2004 30 951-954. (doi:10.1081/ERC-200044170)

87 Louiset E, Contesse V, Groussin L, Cartier D, Duparc C, Barrande G, Bertherat J, Vaudry H \& Lefebvre H. Expression of serotonin7 receptor and coupling of ectopic receptors to protein kinase A and ionic currents in adrenocorticotropin-independent macronodular adrenal hyperplasia causing Cushing's syndrome. Journal of Clinical Endocrinology and Metabolism 200691 4578-4586. (doi:10.1210/jc. 2006-0538)

88 Fujii H, Tamamori-Adachi M, Uchida K, Susa T, Nakakura T, Hagiwara $\mathrm{H}$, Iizuka $\mathrm{M}$, Okinaga $\mathrm{H}$, Tanaka Y \& Okazaki T. Marked cortisol production by intracrine ACTH in GIP-treated cultured adrenal cells in which the GIP receptor was exogenously introduced. PLoS ONE 20149 e110543. (doi:10.1371/journal.pone.0110543)

89 Lacroix A. Heredity and cortisol regulation in bilateral macronodular adrenal hyperplasia. New England Journal of Medicine 2013369 2147-2149. (doi:10.1056/NEJMe1312792)

90 Stratakis CA, Sarlis N, Kirschner LS, Carney JA, Doppman JL, Nieman LK, Chrousos GP \& Papanicolaou DA. Paradoxical response to dexamethasone in the diagnosis of primary pigmented nodular adrenocortical disease. Annals of Internal Medicine 1999131 585-591. (doi:10.7326/0003-4819-131-8-199910190-00006)

91 Louiset E, Stratakis CA, Perraudin V, Griffin KJ, Libe R, Cabrol S, Feve B, Young J, Groussin L, Bertherat J et al. The paradoxical increase in cortisol secretion induced by dexamethasone in primary pigmented nodular adrenocortical disease involves a glucocorticoid receptormediated effect of dexamethasone on protein kinase A catalytic subunits. Journal of Clinical Endocrinology and Metabolism 200994 2406-2413. (doi:10.1210/jc.2009-0031)

92 Bourdeau I, Lacroix A, Schurch W, Caron P, Antakly T \& Stratakis CA. Primary pigmented nodular adrenocortical disease: paradoxical responses of cortisol secretion to dexamethasone occur in vitro and are associated with increased expression of the glucocorticoid receptor. Journal of Clinical Endocrinology and Metabolism 200388 3931-3937. (doi:10.1210/jc.2002-022001)

93 Caticha O, Odell WD, Wilson DE, Dowdell LA, Noth RH, Swislocki AL, Lamothe JJ \& Barrow R. Estradiol stimulates cortisol production by adrenal cells in estrogen-dependent primary adrenocortical nodular dysplasia. Journal of Clinical Endocrinology and Metabolism $1993 \mathbf{7 7}$ 494-497. (doi:10.1210/jcem.77.2.8345057)
94 Bram Z, Wils J, Ragazzon B, Risk-Rabin M, Libe R, Young J, Vantyghem M-C, Martinez A, Stratakis CA, Bertherat JY, et al. $\beta$-estradiol $\left(\mathrm{E}_{2}\right)$ stimulates cortisol secretion in primary pigmented nodular adrenal disease: an explanation for the increased frequency of Cushing's syndrome in female patients with Carney complex. The Endocrine Society's 96th Meeting and 16th International Congress of Endocrinology (ICE-ENDO 2014), Chicago, June 21-24 2014 - Abstract OR14-12.

95 Choi M, Scholl UI, Yue P, Bjorklund P, Zhao B, Nelson-Williams C, Ji W, Cho Y, Patel A, Men CJ et al. $\mathrm{K}^{+}$channel mutations in adrenal aldosterone-producing adenomas and hereditary hypertension. Science 2011331 768-772. (doi:10.1126/science.1198785)

96 Scholl UI, Goh G, Stolting G, de Oliveira RC, Choi M, Overton JD, Fonseca AL, Korah R, Starker LF, Kunstman JW et al. Somatic and germline CACNA1D calcium channel mutations in aldosteroneproducing adenomas and primary aldosteronism. Nature Genetics 2013 45 1050-1054. (doi:10.1038/ng.2695)

97 Beuschlein F, Boulkroun S, Osswald A, Wieland T, Nielsen HN, Lichtenauer UD, Penton D, Schack VR, Amar L, Fischer E et al. Somatic mutations in ATP1A1 and ATP2B3 lead to aldosterone-producing adenomas and secondary hypertension. Nature Genetics $2013 \mathbf{4 5}$ pp 440-444, 444e441-442. (doi:10.1038/ng.2550)

98 Zennaro MC, Boulkroun S \& Fernandes-Rosa F. An update on novel mechanisms of primary aldosteronism. Journal of Endocrinology 2015 224 R63-R77. (doi:10.1530/JOE-14-0597)

99 Zwermann O, Suttmann Y, Bidlingmaier M, Beuschlein F \& Reincke M. Screening for membrane hormone receptor expression in primary aldosteronism. European Journal of Endocrinology 2009160 443-451. (doi:10.1530/EJE-08-0711)

100 Schubert B, Fassnacht M, Beuschlein F, Zenkert S, Allolio B \& Reincke M. Angiotensin II type 1 receptor and ACTH receptor expression in human adrenocortical neoplasms. Clinical Endocrinology 200154 627-632. (doi:10.1046/j.1365-2265.2001.01253.x)

101 Ye P, Mariniello B, Mantero F, Shibata H \& Rainey WE. G-proteincoupled receptors in aldosterone-producing adenomas: a potential cause of hyperaldosteronism. Journal of Endocrinology 2007195 39-48. (doi:10.1677/JOE-07-0037)

102 Arnaldi G, Mancini V, Costantini C, Giovagnetti M, Petrelli M, Masini A, Bertagna X \& Mantero F. ACTH receptor mRNA in human adrenocortical tumors: overexpression in aldosteronomas. Endocrine Research 199824 845-849. (doi:10.3109/07435809809032695)

103 Lefebvre H, Cartier D, Duparc C, Lihrmann I, Contesse V, Delarue C, Godin M, Fischmeister R, Vaudry H \& Kuhn JM. Characterization of serotonin(4) receptors in adrenocortical aldosterone-producing adenomas: in vivo and in vitro studies. Journal of Clinical Endocrinology and Metabolism 200287 1211-1216. (doi:10.1210/jcem.87.3.8327)

104 Saner-Amigh K, Mayhew BA, Mantero F, Schiavi F, White PC, Rao CV $\&$ Rainey WE. Elevated expression of luteinizing hormone receptor in aldosterone-producing adenomas. Journal of Clinical Endocrinology and Metabolism 200691 1136-1142. (doi:10.1210/jc.2005-1298)

105 Mune T, Murase H, Yamakita N, Fukuda T, Murayama M, Miura A, Suwa T, Hanafusa J, Daido H, Morita H et al. Eutopic overexpression of vasopressin v1a receptor in adrenocorticotropin-independent macronodular adrenal hyperplasia. Journal of Clinical Endocrinology and Metabolism 200287 5706-5713. (doi:10.1210/jc.2002-020067)

106 Perraudin V, Delarue C, Lefebvre H, Do Rego JL, Vaudry H \& Kuhn JM. Evidence for a role of vasopressin in the control of aldosterone secretion in primary aldosteronism: in vitro and in vivo studies. Journal of Clinical Endocrinology and Metabolism 200691 1566-1572. (doi:10.1210/jc.2005-1453)

107 Rossi GP, Ganzaroli C, Cesari M, Maresca A, Plebani M, Nussdorfer GG $\&$ Pessina AC. Endothelin receptor blockade lowers plasma aldosterone levels via different mechanisms in primary aldosteronism and high-to-normal renin hypertension. Cardiovascular Research 200357 277-283. (doi:10.1016/S0008-6363(02)00658-2) 
108 Cartier D, Jegou S, Parmentier F, Lihrmann I, Louiset E, Kuhn JM, Bastard C, Plouin PF, Godin M, Vaudry H et al. Expression profile of serotonin 4 (5-HT4) receptors in adrenocortical aldosterone-producing adenomas. European Journal of Endocrinology 2005153 939-947. (doi:10.1530/eje.1.02051)

109 Gross MD, Grekin RJ, Gniadek TC \& Villareal JZ. Suppression of aldosterone by cyproheptadine in idiopathic aldosteronism. New England Journal of Medicine 1981305 181-185. (doi:10.1056/ NEJM198107233050401)

110 Mantero F, Rocco S, Opocher G, Armanini D, Boscaro M \& D'Agostino D. Effect of ketanserin in primary aldosteronism. Journal of Cardiovascular Pharmacology 19857 (Suppl 7) S172-S175. (doi:10. 1097/00005344-198500077-00048)

111 Ehrhart-Bornstein M, Hinson JP, Bornstein SR, Scherbaum WA \& Vinson GP. Intraadrenal interactions in the regulation of adrenocortical steroidogenesis. Endocrine Reviews 199819 101-143. (doi:10.1210/edrv.19.2.0326)

112 Lefebvre H, Compagnon P, Contesse V, Delarue C, Thuillez C, Vaudry H \& Kuhn JM. Production and metabolism of serotonin (5-HT) by the human adrenal cortex: paracrine stimulation of aldosterone secretion by 5-HT. Journal of Clinical Endocrinology and Metabolism 200186 5001-5007. (doi:10.1210/jcem.86.10.7917)

113 Maltby S, Khazaie K \& McNagny KM. Mast cells in tumor growth: angiogenesis, tissue remodelling and immune-modulation. Biochimica et Biophysica Acta 20091796 19-26. (doi:10.1016/j.bbcan. 2009.02.001)

114 Soucek L, Lawlor ER, Soto D, Shchors K, Swigart LB \& Evan GI. Mast cells are required for angiogenesis and macroscopic expansion of Mycinduced pancreatic islet tumors. Nature Medicine 200713 1211-1218. (doi:10.1038/nm1649)

115 Duparc C, Moreau L, Felipe Golib Dzib J, Boyer HG, Tetsi Nomigni M, Boutelet I, Boulkroun S, Mukai K, Benecke AG, Amar L et al. Mast cell hyperplasia is associated with aldosterone hypersecretion in a subset of aldosterone-producing adenomas. Journal of Clinical Endocrinology and Metabolism 2015100 E550-E560. (doi:10.1210/jc.2014-3660)

116 Lampron A, Bourdeau I, Oble S, Godbout A, Schurch W, Arjane P, Hamet P \& Lacroix A. Regulation of aldosterone secretion by several aberrant receptors including for glucose-dependent insulinotropic peptide in a patient with an aldosteronoma. Journal of Clinical Endocrinology and Metabolism 200994 750-756. (doi:10.1210/ jc.2008-1340)

117 Lacroix A, Tremblay J, Rousseau G, Bouvier M \& Hamet P. Propranolol therapy for ectopic $\beta$-adrenergic receptors in adrenal Cushing's syndrome. New England Journal of Medicine 1997337 1429-1434. (doi:10.1056/NEJM199711133372004)

118 Albiger NM, Sartorato P, Mariniello B, Iacobone M, Finco I, Fassina A \& Mantero F. A case of primary aldosteronism in pregnancy: do LH and GNRH receptors have a potential role in regulating aldosterone secretion? European Journal of Endocrinology 2011164 405-412. (doi:10.1530/EJE-10-0879)

119 Tsagarakis S, Tsigos C, Vassiliou V, Tsiotra P, Pratsinis H, Kletsas D, Trivizas P, Nikou A, Mavromatis T, Sotsiou F et al. Food-dependent androgen and cortisol secretion by a gastric inhibitory polypeptidereceptor expressive adrenocortical adenoma leading to hirsutism and subclinical Cushing's syndrome: in vivo and in vitro studies. Journal of Clinical Endocrinology and Metabolism 200186 583-589. (doi:10.1210/ jcem.86.2.7171)

120 Leinonen P, Ranta T, Siegberg R, Pelkonen R, Heikkila P \& Kahri A. Testosterone-secreting virilizing adrenal adenoma with human chorionic gonadotrophin receptors and 21-hydroxylase deficiency. Clinical Endocrinology 199134 31-35. (doi:10.1111/j.1365-2265.1991. tb01732.x)

121 Goodarzi MO, Dawson DW, Li X, Lei Z, Shintaku P, Rao CV \& Van Herle AJ. Virilization in bilateral macronodular adrenal hyperplasia controlled by luteinizing hormone. Journal of Clinical Endocrinology and Metabolism 200388 73-77. (doi:10.1210/jc.2002-021292)
122 Dahia PL, Ahmed-Shuaib A, Jacobs RA, Chew SL, Honegger J, Fahlbusch R, Besser GM \& Grossman AB. Vasopressin receptor expression and mutation analysis in corticotropin-secreting tumors. Journal of Clinical Endocrinology and Metabolism 199681 1768-1771. (doi:10.1210/jcem.81.5.8626831)

123 Wang FF, Tang KT, Yen YS, Ho DM, Yang AH, Huang CI, Lin HD \& Won JG. Plasma corticotrophin response to desmopressin in patients with Cushing's disease correlates with the expression of vasopressin receptor 2, but not with that of vasopressin receptor 1 or 3, in their pituitary tumours. Clinical Endocrinology 201276 253-263. (doi:10.1111/j.1365-2265.2011.04179.x)

124 Luque RM, Ibanez-Costa A, Lopez-Sanchez LM, Jimenez-Reina L, Venegas-Moreno E, Galvez MA, Villa-Osaba A, Madrazo-Atutxa AM, Japon MA, de la Riva A et al. A cellular and molecular basis for the selective desmopressin-induced ACTH release in Cushing disease patients: key role of AVPR1b receptor and potential therapeutic implications. Journal of Clinical Endocrinology and Metabolism 201398 4160-4169. (doi:10.1210/jc.2013-1992)

125 Ghigo E, Arvat E, Ramunni J, Colao A, Gianotti L, Deghenghi R, Lombardi G \& Camanni F. Adrenocorticotropin- and cortisolreleasing effect of hexarelin, a synthetic growth hormone-releasing peptide, in normal subjects and patients with Cushing's syndrome. Journal of Clinical Endocrinology and Metabolism 199782 2439-2444. (doi:10.1210/jcem.82.8.4132)

126 Martinez-Fuentes AJ, Moreno-Fernandez J, Vazquez-Martinez R, Duran-Prado M, de la Riva A, Tena-Sempere M, Dieguez C, JimenezReina L, Webb SM, Pumar A et al. Ghrelin is produced by and directly activates corticotrope cells from adrenocorticotropin-secreting adenomas. Journal of Clinical Endocrinology and Metabolism 200691 2225-2231. (doi:10.1210/jc.2006-0235)

127 Fukuoka H, Cooper O, Ben-Shlomo A, Mamelak A, Ren SG, Bruyette D $\&$ Melmed S. EGFR as a therapeutic target for human, canine, and mouse ACTH-secreting pituitary adenomas. Journal of Clinical Investigation 2011121 4712-4721. (doi:10.1172/JCI60417)

128 Reincke M, Sbiera S, Hayakawa A, Theodoropoulou M, Osswald A, Beuschlein F, Meitinger T, Mizuno-Yamasaki E, Kawaguchi K, Saeki Y et al. Mutations in the deubiquitinase gene USP8 cause Cushing's disease. Nature Genetics 201547 31-38. (doi:10.1038/ng.3166)

129 Ma ZY, Song ZJ, Chen JH, Wang YF, Li SQ, Zhou LF, Mao Y, Li YM, Hu RG, Zhang ZY et al. Recurrent gain-of-function USP8 mutations in Cushing's disease. Cell Research 201525 306-317. (doi:10.1038/cr. 2015.20)

130 Schorr I, Hinshaw HT, Cooper MA, Mahaffee D \& Ney RL. Adenyl cyclase hormone responses of certain human endocrine tumors. Journal of Clinical Endocrinology and Metabolism 197234 447-451. (doi:10.1210/jcem-34-3-447)

131 Guillemot J, Compagnon P, Cartier D, Thouennon E, Bastard C, Lihrmann I, Pichon P, Thuillez C, Plouin PF, Bertherat J et al. Metoclopramide stimulates catecholamine- and granin-derived peptide secretion from pheochromocytoma cells through activation of serotonin type 4 (5-HT4) receptors. Endocrine-Related Cancer 2009 16 281-290. (doi:10.1677/ERC-08-0190)

132 Ziegler CG, Brown JW, Schally AV, Erler A, Gebauer L, Treszl A, Young L, Fishman LM, Engel JB, Willenberg HS et al. Expression of neuropeptide hormone receptors in human adrenal tumors and cell lines: antiproliferative effects of peptide analogues. PNAS 2009106 15879-15884. (doi:10.1073/pnas.0907843106)

133 Umahara M, Okada S, Ohshima K \& Mori M. Glucose-dependent insulinotropic polypeptide induced growth hormone secretion in acromegaly. Endocrine Journal 200350 643-650. (doi:10.1507/endocrj. 50.643)

134 Occhi G, Losa M, Albiger N, Trivellin G, Regazzo D, Scanarini M, Monteserin-Garcia JL, Frohlich B, Ferasin S, Terreni MR et al. The glucose-dependent insulinotropic polypeptide receptor is overexpressed amongst GNAS1 mutation-negative somatotropinomas and drives growth hormone (GH)-promoter activity in GH3 cells. Journal of 
Neuroendocrinology 201123 641-649. (doi:10.1111/j.1365-2826.2011. 02155.x)

135 Matsukura S, Kakita T, Hirata Y, Yoshimi H \& Fukase M. Adenylate cyclase of GH and ACTH producing tumors of human: activation by non-specific hormones and other bioactive substances. Journal of Clinical Endocrinology and Metabolism 197744 392-397. (doi:10.1210/ jcem-44-2-392)

136 Lawrence AM, Goldfine ID \& Kirsteins L. Growth hormone dynamics in acromegaly. Journal of Clinical Endocrinology and Metabolism 197031 239-247. (doi:10.1210/jcem-31-3-239)

137 Hanew K, Kokubun M, Sasaki A, Mouri T \& Yoshinaga K. The spectrum of pituitary growth hormone responses to pharmacological stimuli in acromegaly. Journal of Clinical Endocrinology and Metabolism 198051 292-297. (doi:10.1210/jcem-51-2-292)

138 Konaka S, Yamada M, Satoh T, Ozawa H, Watanabe E, Takata K \& Mori M. Expression of thyrotropin-releasing hormone (TRH) receptor mRNA in somatotrophs in the rat anterior pituitary. Endocrinology 1997138 827-830. (doi:10.1210/endo.138.2.5030)

139 Arihara Z, Sakurai K, Osaki Y, Fukazawa H, Yamada S, Inoshita N, Murakami O, Ohba K \& Takahashi K. ACTH response to desmopressin in a patient with acromegaly; expression of corticotropin-releasing factor, urocortins and vasopressin V1b receptor in GH-producing pituitary adenoma. Endocrine Journal 201158 1029-1036. (doi:10.1507/endocrj.EJ11-0038)

140 Albiger NM, Ceccato F, Zilio M, Barbot M, Occhi G, Rizzati S, Fassina A, Mantero F, Boscaro M, Iacobone $\mathrm{M}$ et al. An analysis of different therapeutic options in patients with Cushing's syndrome due to bilateral macronodular adrenal hyperplasia: a single-centre experience. Clinical Endocrinology 201582 808-815. (doi:10.1111/cen. 12763)

141 Mazzuco TL, Thomas M, Martinie M, Cherradi N, Sturm N, Feige JJ \& Chabre O. Cellular and molecular abnormalities of a macronodular adrenal hyperplasia causing $\beta$-blocker-sensitive Cushing's syndrome. Arquivos Brasileiros de Endocrinologia e Metabologia 200751 1452-1462. (doi:10.1590/S0004-27302007000900007)

142 Preumont V, Mermejo LM, Damoiseaux P, Lacroix A \& Maiter D. Transient efficacy of octreotide and pasireotide (SOM230) treatment in GIP-dependent Cushing's syndrome. Hormone and Metabolic Research 201143 287-291. (doi:10.1055/s-0030-1270523)

143 Karapanou O, Vlassopoulou B, Tzanela M, Stratigou T, Tsatlidis V, Tsirona $S \&$ Tsagarakis $S$. Adrenocorticotropic hormone independent macronodular adrenal hyperplasia due to aberrant receptor expression: is medical treatment always an option? Endocrine Practice 201319 e77-e82. (doi:10.4158/EP12346.CR)

144 Daidoh H, Morita H, Hanafusa J, Mune T, Murase H, Sato M, Shibata T, Suwa T, Ishizuka T \& Yasuda K. In vivo and in vitro effects of AVP and V1a receptor antagonist on Cushing's syndrome due to ACTHindependent bilateral macronodular adrenocortical hyperplasia. Clinical Endocrinology 199849 403-409. (doi:10.1046/j.1365-2265. 1998.00490.x)

145 Nakamura Y, Son Y, Kohno Y, Shimono D, Kuwamura N, Koshiyama H, Sasano H \& Matsuda T. Case of adrenocorticotropic hormone-independent macronodular adrenal hyperplasia with possible adrenal hypersensitivity to angiotensin II. Endocrine $2001 \mathbf{1 5}$ 57-61. (doi:10.1385/ENDO:15:1:057)

146 Mazzuco TL, Chaffanjon P, Martinie M, Sturm N \& Chabre O. Adrenal Cushing's syndrome due to bilateral macronodular adrenal hyperplasia: prediction of the efficacy of $\beta$-blockade therapy and interest of unilateral adrenalectomy. Endocrine Journal 200956 867-877. (doi:10.1507/endocrj.K08E-370)

147 Fragoso MC, Alencar GA, Lerario AM, Bourdeau I, Almeida MQ, Mendonca BB \& Lacroix A. Genetics of primary macronodular adrenal hyperplasia. Journal of Endocrinology 2015224 R31-R43. (doi:10.1530/ JOE-14-0568)

148 Plöckinger U, Tiling N, Blankenstein O, von Weizsäcker K, Allolio B, Kroiss M, Hauptmann K, Saeger W, Radke C, Steinmüller T et al. Transient pregnancy-induced Cushing's syndrome with aberrant adrenal hCG receptor. Experimental and Clinical Endocrinology \& Diabetes 2014122 P137. (doi:10.1055/s-0034-1372154)

149 Lefebvre H, Prévost G \& Louiset E. Could targeting hormone receptors be an effective strategy in management of adrenal hyperplasia? International Journal of Endocrine Oncology 20141 11-14. (doi:10.2217/ ije.14.10)

Received 19 February 2015

Revised version received 21 April 2015

Accepted 12 May 2015 